\title{
Caracterización de variables físicas en La Escollera, una laguna costera artificial en Santa Marta, Caribe colombiano
}

\section{Characterization of physical variables at La Escollera, a human- made coastal lagoon in Santa Marta, Colombian Caribbean}

\author{
Sven Zea ${ }^{l}$ y Nicolás Espada Gómez-Lor ${ }^{2}$ \\ $\begin{array}{ll}\text { (D) 0000-0002-5657-4877 } & \text { (iD) 0000-0001-5995-1124 }\end{array}$ \\ 1. Instituto de Estudios en Ciencias del Mar (Cecimar), Universidad Nacional de Colombia, sede Caribe, clo Invemar, Santa Marta, Colombia. \\ sezeas@unal.edu.co* \\ 2. Facultad de Ciencias, Ciudad Universitaria de Cantoblanco, Universidad Autónoma de Madrid, Madrid, España.nicolasespada11@hotmail.com \\ * Corresponding author.
}

\section{RESUMEN}

$\mathrm{L}$ as lagunas costeras son foco de producción primaria y refugio de biodiversidad por su relativo confinamiento y baja profundidad. La Escollera es una laguna costera artificial situada en El Rodadero, Santa Marta (Caribe colombiano), excavada al inicio de la década de 1980 para albergar una marina y sus bordes sembrados con mangles. Para generar una línea base de variables físicas que contribuyan al entendimiento de la circulación del agua y de su influencia sobre los atributos del ecosistema, se obtienen de manera rutinaria datos de salinidad, temperatura, nivel del mar y penetración de la luz mediante registradores electrónicos y sensores de mano. Los datos de salinidad y temperatura entre enero de 2017 y febrero de 2018 siguieron el esquema estacional del mar abierto del área de Santa Marta alternando entre menor temperatura (mínima $24,6{ }^{\circ} \mathrm{C}$ ) y mayor salinidad (máxima 38,9) en época seca y de afloramiento costero (diciembre a abril) y entre mayor temperatura (máxima $34,7^{\circ} \mathrm{C}$ ) y menor salinidad $(<35)$ en época de lluvia (mayo a noviembre), con los más bajos valores de salinidad luego de aguaceros persistentes (mínimo 15,1). La columna de agua está generalmente bien mezclada y se estratifica después de aguaceros en época de lluvia (mezclándose rápidamente en horas o en días). Esto parece deberse principalmente al intercambio con el mar gracias a la marea, que oscila de $+0,37$ a $-0,31 \mathrm{~m}$ (rango máximo de $0,68 \mathrm{~m}$ [datos de un año]), y sigue el patrón astronómico regular de mareas mixtas del Caribe. Las aguas de la laguna son regularmente verdes y de variada transparencia excepto durante fuertes lluvias, tras lo cual se tornan pardas. La extinción de luz en la vertical es en general alta y no muy variable $\left(2-6,5 \% \mathrm{~cm}^{-1}\right)$, pero la luz, con frecuencia, alcanza el fondo, lo que permite la existencia de macroalgas bentónicas en algunas porciones de la laguna.

PALABRAS CLAVE: lagunas costeras, marinas, mareas, salinidad, temperatura

\section{ABSTRACT}

$\mathrm{C}$ oastal lagoons are a focus of primary production and a refuge for biodiversity due to their relative confinement and low depth. La Escollera is a human-made coastal lagoon in El Rodadero, Santa Marta (Colombian Caribbean), excavated in the early 1980s understang Tout routinely obtained through electronic recorders and handheld sensors. Salinity and temperature data from January 2017 to February 2018 followed the seasonal pattern of the open sea in the Santa Marta area, alternating between lower temperature (minimum of $24.6{ }^{\circ} \mathrm{C}$ ) and higher salinity (maximum of 38.9) in the dry season and coastal upwelling (December to April), an between higher temperature (maximum $34.7^{\circ} \mathrm{C}$ ) and lower salinity $(<35)$ in the rainy season (May to November), with the lowest salinity values after persistent rains (minimum 15.1). The water column is generally well mixed and stratified after heavy showers in the rainy season (mixing rapidly in hours or days). This seems to be mainly due to tidal exchange with the sea, the tide oscillating from +0.37 to $-0.31 \mathrm{~m}$ (maximum range $0.68 \mathrm{~m}$ [one-year data]), and following the regular astronomical pattern of mixed tides in the Caribbean. Lagoon waters are regularly green and of varied transparency except during heavy rains, after which they become brownish. Vertical light extinction is generally high and not very variable $\left(2-6.5 \% \mathrm{~cm}^{-1}\right)$, but the light frequently reaches the bottom, which allows the presence of benthic macroalgae in some portions of the lagoon.

KEY WORDS: coastal lagoons, marinas, tides, salinity, temperature

DOI: https://doi.org/10.25268/bimc.invemar.2020.49.2.925 Publicado por INVEMAR

Este es un manuscrito de acceso abierto bajo la licencia CC

Published by INVEMAR

Reconocimiento-No Comercial-Compartir Igual 


\section{INTRODUCCIÓN}

Las lagunas costeras son cuerpos de agua marina localizados costa adentro y separados del mar por la formación de barreras, o dentro de planicies de inundación, con una o más conexiones con el mar, temporales o permanentes (Kjerfve y Magill, 1989; Kjervfe, 1994). Allí, fuerzas de tierra y mar, escorrentía del lado terrestre y olas del lado marino colisionan y se amortiguan. Son fuente o sumidero de producción primaria y secundaria e importantes repositorios de biodiversidad costera, siendo guarderías de una gran variedad de larvas y juveniles de invertebrados y peces, muchos de estos de importancia comercial (Barnes, 1980; Mitsch y Gosselink, 1993; Gopal et al., 2000). Las lagunas costeras son impactadas con frecuencia por actividades humanas, en especial por desarrollo costero (de Jonge et al., 2002). Las marinas, construidas en entradas o separadas del mar abierto por paredes o espolones, se constituyen efectivamente en lagunas costeras. Como nuevo ecosistema proveen los beneficios mencionados arriba, pero también causan impactos, en especial si su drenaje es pobre, o si afectan la circulación local, o si las actividades náuticas y la escorrentía asociada causan contaminación o la llegada de especies foráneas (Foster et al., 2016). La circulación en las lagunas costeras está influenciada por descargas de ríos y escorrentía, vientos, mareas, seiches, y por el balance entre evaporación y precipitación, y responde diferencialmente a estos dependiendo de su localización y geomorfología $(v$. g. Kjerevfe, 1994; Niedda y Greppi, 2007; Montaño-Ley et al., 2008). La circulación en marinas o sistemas mixtos también se afecta diferencialmente por estos factores ( $v . g$. Nece y Falconer, 1989; Lonin y Mendoza, 1997; VelásquezMontoya y Overton, 2017; Lončar et al., 2018).

En el Caribe continental colombiano hay numerosas lagunas costeras, de las cuales la Ciénaga Grande de Santa Marta es la más grande y productiva (Hernández y Gocke, 1990; Sánchez y Zea, 2000; Polanía et al., 2001; Gocke et al., 2003). Alrededor de la ciudad de Santa Marta, la planicie costera todavía tiene algunos playones salinos supramareales con lagunas de inundación.

Para ubicar una marina privada con fines turísticos, al inicio de la década de 1980 en el sector norte de El Rodadero se excavó una laguna somera (de aproximadamente $2 \mathrm{~m}$ de profundidad) con un canal de comunicación con el mar. En los contornos de la laguna y el canal se plantaron manglares, lo que creó un ambiente semicerrado, con un aparente buen estado de conservación, como si fuera una laguna natural

\section{INTRODUCTION}

Coastal lagoons are bodies of marine water located inside the coast, separated from the sea by the formation of barriers, or within flood plains, with one or more permanent or temporal connections with the sea (Kjerfve and Magill, 1989; Kjervfe, 1994). They act as buffer of both land and sea forces, dampening runoff from the land side and waves from the marine side, being source or sink of primary and secondary production. They are important repositories of coastal biodiversity, nursing a great variety of larvae and juveniles of invertebrates and fishes, many of those having commercial importance (Barnes, 1980; Mitsch and Gosselink, 1993; Gopal et al., 2000). They are frequently impacted by human activities, especially coastal development (de Jonge et al., 2002). Marinas built in inlets or secluded from the open sea by seawalls and jetties become in effect coastal lagoons. As a new ecosystem, they provide the benefits mentioned above, but also cause impacts, especially if their flushing is poor, or if they affect local circulation, or if boating activities and associated runoff cause pollution or arrival of non-native species (Foster et al., 2016). Coastal lagoon circulation is influenced by river discharges and runoff, winds, tides, seiches, and the balance between evaporation and precipitation, and respond differently to those depending on their localization and geomorphology (e.g., Kjerevfe, 1994; Niedda and Greppi, 2007; Montaño-Ley et al., 2008). Circulation in marinas or mixed systems is also differentially affected by these factors (e.g., Nece and Falconer, 1989; Lonin and Mendoza, 1997; Velásquez-Montoya and Overton, 2017; Lončar et al., 2018).

In the continental Colombian Caribbean there are numerous coastal lagoons, being Ciénaga Grande de Santa Marta the largest and most productive (Hernández and Gocke, 1990; Sánchez y Zea, 2000; Polanía et al., 2001; Gocke et al., 2003). Around the Santa Marta city, the coastal plain still has a few remaining supratidal salt flats with flood lagoons.

To harbor a private marina for touristic development, a shallow (ca. $2 \mathrm{~m}$ deep) lagoon was excavated during the early 1980s in the northern sector of El Rodadero, with a channel opening to the sea. The contours of the lagoon and channel were planted with mangroves, creating a semi-enclosed environment, with apparent good conservation status, as if it were a natural lagoon (see also Martínez-Clavijo, 2013). From having a single connection 
(ver también Martínez-Clavijo, 2013). Por tener una sola conexión con el mar, se hipotetiza que la marea es un importante motor de la circulación y la mezcla, pero otros factores físicos como el viento, la lluvia y la irradiación, al operar a escalas estacionales y diarias, pueden ser también significativos, y todos, en últimas, influenciar la producción primaria (v. g. Elliott et al., 2001; Rodríguez-Chila et al., 2009). El área experimenta una época seca, de diciembre a abril, y una de lluvia, de mayo a noviembre. En la época seca, se espera que las aguas de la laguna sean más salinas y calientes por la falta de lluvia y evaporación (por la luz solar y los fuertes vientos alisios), pero pueden ser diluidas y enfriadas ligeramente por aguas que afloran mar afuera y que pueden entrar a la laguna por el canal por las mareas, y enfriadas durante la noche desde el aire por las temperaturas ligeramente menores del invierno del hemisferio norte. En la época de lluvia, se espera que las salinidades sean menores por la escorrentía local y por intercambio a través del canal de aguas costeras, que son, en general, menos salinas por la descarga de ríos cercanos. Las mayores temperaturas en el verano y el otoño del hemisferio norte pueden bajar por cielos nublados y luego de fuertes lluvias. También se espera que las aguas de la laguna estén estratificadas verticalmente luego de fuertes lluvias, pero, por lo demás, deben estar bien mezcladas por la circulación forzada de la marea o los vientos.

Se aprovechó la localización de La Escollera dentro de los límites de la ciudad, la seguridad que brinda el hecho de estar cercada y su relativa simplicidad y pequeño tamaño para usarla como un laboratorio natural con propósitos académicos e investigativos. Desde 2015 se han estado midiendo variables físicas como temperatura, salinidad, nivel del mar y penetración de la luz (Zea et al., 2017). El propósito de este artículo es describir el comportamiento de estas variables durante un año para proveer una línea base acerca de su variación estacional y diaria y probar parcialmente las hipótesis presentadas arriba, como una contribución inicial al entendimiento de las variables que impulsan la circulación.

\section{ÁREA DE ESTUDIO}

La laguna La Escollera $\left(11^{\circ} 12^{\prime} 32,83^{\prime \prime} \quad \mathrm{N}\right.$, $74^{\circ} 13^{\prime} 31,68^{\prime \prime} \mathrm{W}$ ) es una marina artificial privada localizada en el extremo norte de la ensenada de Gaira, en el sector turístico de El Rodadero, Santa Marta (Colombia), en el mar Caribe (Figura 1, ver una descripción de Gaira en Franco, 2005). La laguna (con una isla en el centro) se excavó a with the sea, we hypothesize that the tide is an important forcing agent of circulation and mixing, but other physical factors such as winds, rainfall and irradiance, operating at seasonal and daily scales, may influence circulation and mixing, ultimately determining primary production (e.g., Elliott et al., 2001; Rodríguez-Chila et al., 2009). The area experiences a dry season, from December to April, and a rainy season, from May to November. During the dry season, lagoon waters are expected to be more saline and warm from lack of rain and evaporation (from sunlight and strong trade winds), but they could be diluted and cooled by off-shore upwelled waters that may enter the lagoon through the channel via tides, and cooled overnight from the air by the slightly lower temperatures of the northern hemisphere winter. During the rainy season, salinities are expected to be lower from local runoff and from exchange through the channel of coastal waters that are generally less saline from nearby riverine discharge. The higher temperatures of the northern hemisphere summer and fall could also be occasionally lower from overcast skies and during and after heavy rainfall. Lagoon waters are also expected to be vertically stratified after heavy rainfall, but otherwise they should be well-mixed from tidal, thermohaline or winddriven circulation.

Taking advantage of the location within the city limits, its enclosed and thus secure settings, and its relative simplicity and small size, we are using La Escollera as a natural laboratory for academic and research purposes. Since 2015, we have been measuring environmental variables such as temperature, salinity, water level and light penetration (Zea et al., 2017). The purpose of this paper is to describe the behavior of these variables throughout a year to provide a baseline of their seasonal and daily variations and to partially test the hypotheses presented above, as an initial contribution to the understanding of the variables forcing circulation.

\section{STUDY AREA}

La Escollera lagoon $\left(11^{\circ} 12^{\prime} 32,83^{\prime \prime} \quad \mathrm{N}\right.$, $\left.74^{\circ} 13^{\prime} 31,68^{\prime \prime} \mathrm{W}\right)$ is a human-made private marina located in the northern extreme of Ensenada de Gaira, in the touristic sector El Rodadero, Santa Marta city, Colombia, Caribbean Sea (Figure 1) (see Franco, 2005 for a description of Gaira). The lagoon itself (with an island in the center) was dug out in the early 1980s on the coastal plain, in the supratidal salt flat. It communicates with the nearby ocean through a rather straight, walled channel. On the $\mathrm{W}$ side of the lagoon, 


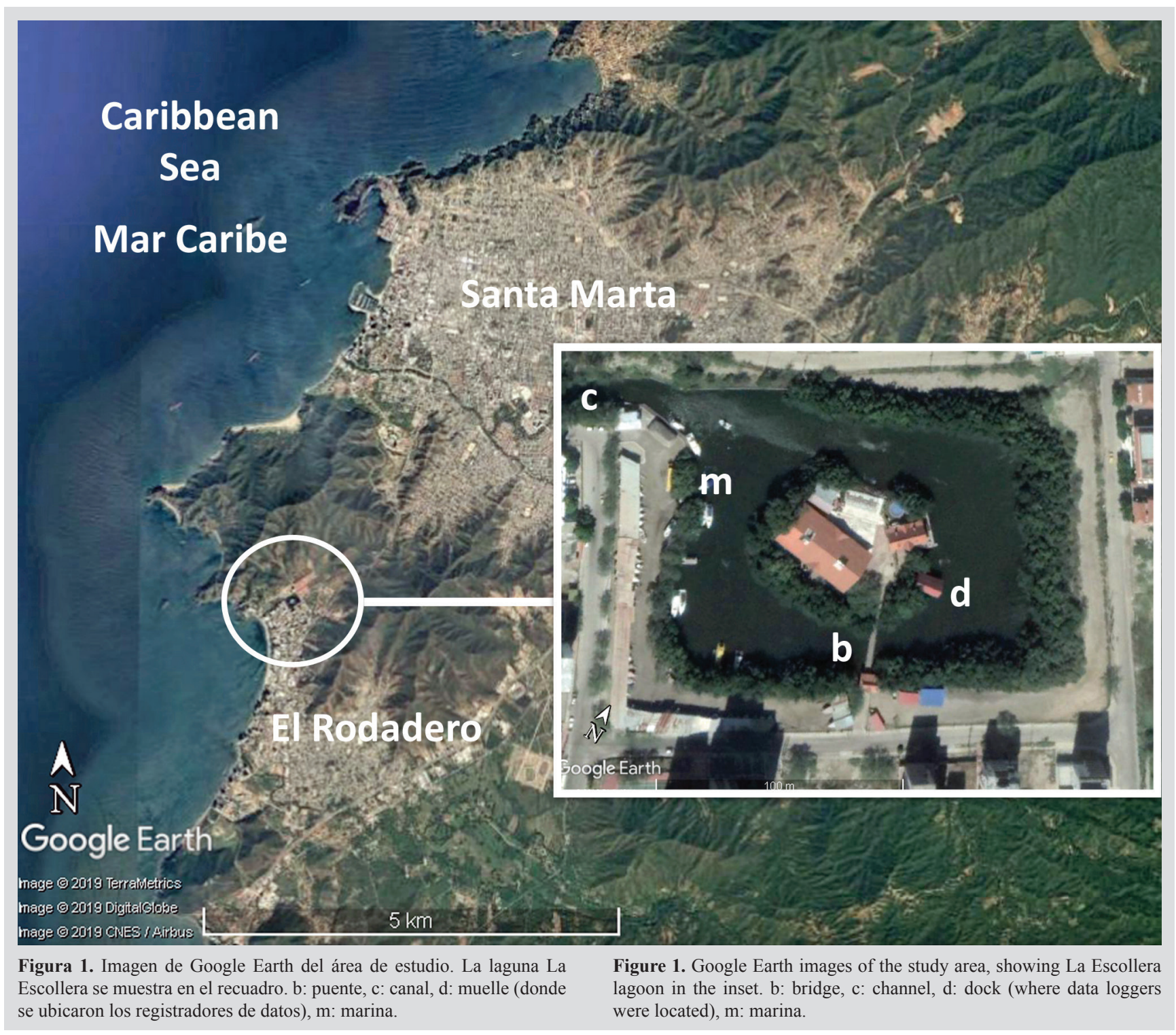

principios de la década de 1980 en la planicie costera, en el playón salino supramareal. Se comunica con el mar por medio de un canal amurallado recto. En el lado occidental de la laguna se construyó una marina (Marina Mundial, $\mathrm{http}: / /$ marinamundial.com/) y en la isla una discoteca (La Escollera, http://www.laescollerarestaurante.inf.travel/).

Alrededor de 1985, se plantaron manglares en los bordes de la laguna y el canal, principalmente el mangle rojo Rhizophora mangle. Hoy en día, están bien desarrollados y preservados como un típico manglar de franja, con árboles que alcanzan $6 \mathrm{~m}$ de altura (J. Medina, com. pers.) y con raíces adventicias que albergan variada fauna y flora (Zea et al., 2017). La única comunicación de La Escollera con el mar es a través del canal (ver también Franco, 2005). No hay quebradas permanentes que desemboquen en la a marina (Marina Mundial, http://marinamundial.com/), and on the island, a popular discotheque (La Escollera, http:// www.laescollerarestaurante.inf.travel/), were built.

Mangroves, mainly red mangrove Rhizophora mangle, were planted around 1985 on the edges of the lagoon and channel, becoming quite well developed and preserved today as a typical fringe mangrove, with trees up to about $6 \mathrm{~m}$ in height (pers. comm. J. Medina), their stilt roots harboring varied fauna and flora (Zea et al., 2017). The only communication with the sea is through the channel (see also Franco, 2005), and there are no permanent streams that open to the lagoon. The whole area is fenced and access to the public restricted, there being an iguana reserve in the southern bank of the channel, for tourists to see from the adjacent walkway (Martínez-Clavijo, 2013). Nowadays 
laguna. Toda el área está cercada y el acceso al público está restringido. Hay una reserva de iguanas en el banco sur del canal para que los turistas las observen desde el andén adyacente (Martínez-Clavijo, 2013). En la actualidad, calles de la ciudad rodean toda la laguna, con dos drenajes (en las esquinas NE y SW, respectivamente), por donde toda la escorrentía del vecindario y de las colinas adyacentes entra a la laguna. La otra entrada de agua salobre puede llegar indirectamente a través del canal, impulsada por las mareas, cuando el flujo del cercano río Gaira es empujado al norte hacia la boca del canal por corrientes y vientos de tormenta del SW (Franco, 2005). No hay descargas directas de aguas servidas en la laguna y el canal (la marina y la discoteca bombean sus residuos directamente en el alcantarillado de la ciudad), pero hay derrames en el alcantarillado durante la época de lluvia y la temporada turística alta (Franco, 2005; Martínez-Clavijo, 2013).

La laguna es rectangular, de alrededor de $167 \times 133 \mathrm{~m}$ (incluyendo la isla y el borde de manglar), y el canal es de unos $400 \mathrm{~m}$ de largo y 9-13 $\mathrm{m}$ de ancho. La profundidad máxima de la laguna es ahora de 2,25 m (normalizada al nivel del mar promedio), pero cerca de la mitad del área es menor de 1,5 m. La profundidad del centro del canal varía entre 1,6 y algo más de $2 \mathrm{~m}$ (datos de batimetría no publicados). El fondo de la laguna es principalmente fangoso, con porciones de acumulaciones de conchas y cascajo; en la porción SE hay unos lechos sueltos, relativamente gruesos (aproximadamente $20 \mathrm{~cm}$ ), del alga verde Caulerpa sertularioides, pero parecen estacionales.

El área de Santa Marta se localiza en las estribaciones NW y en las planicies costeras del macizo de la Sierra Nevada de Santa Marta. Es bastante seca, con una precipitación total anual cercana a $500 \mathrm{~mm}$ (Franco, 2005). El clima alterna entre una estación seca y de afloramiento costero, de diciembre a abril, y una época de lluvia, de mayo a noviembre. En la época de afloramiento, los vientos alisios del NE soplan con alta frecuencia e intensidad, las temperaturas del agua son bajas (para las condiciones del Caribe sur), alrededor de $21-26{ }^{\circ} \mathrm{C}$, y las salinidades son altas (35-38). En la época de lluvia, los alisios merman y los vientos del SW son comunes durante tormentas; el mar es más caliente $\left(27-28^{\circ} \mathrm{C}\right)$ y menos salino (30-35) (Márquez, 1982; Ramírez, 1983, 1990; Salzwedel y Müller, 1983; Blanco, 1988; Franco, 2005). city roads surround the entire lagoon, with two drainage openings, respectively on the NE and SW corners, where all the runoff from the neighborhood and adjacent hills enters the lagoon; the only other brackish water input may come indirectly through the channel, driven by tides, when the nearby Gaira river flow is pushed northwards toward the channel mouth by currents and SW storm winds (Franco, 2005). There are no direct sewage discharges into the lagoon and channel (the marina and disco pump their residues into the city sewer system), but there are sewage overspills of the urban sewer through overflow valves and from the streets during the rainy and the touristic high seasons (Franco, 2005; Martínez-Clavijo, 2013).

The lagoon is rectangular, about $167 \mathrm{~m} \times 133 \mathrm{~m}$ (including the island and the mangrove fringe), and the channel is about $400 \mathrm{~m}$ long and 9-13 $\mathrm{m}$ wide. The maximum depth of the lagoon is currently about $2.25 \mathrm{~m}$ (normalized to the mean sea level), but about half of the lagoon bottom is shallower than $1.50 \mathrm{~m}$; the depth of the center of the channel ranges between 1.6 and slightly more than $2 \mathrm{~m}$ (unpublished bathymetry data). The lagoon bottom is mostly silty, with portions having shell and rubble accumulations; on the SE portion, there are rather thick (about $20 \mathrm{~cm}$ ), loose beds of the green algae, Caulerpa sertularioides, but these appear to be seasonal.

The Santa Marta area is located in the NW foothills and coastal plains of the Sierra Nevada de Santa Marta massif. It is rather dry, with total precipitation usually around $500 \mathrm{~mm}$ (Franco, 2005). The climate alternates between a dry-upwelling season, from December to April, and a rainy season, from May to November. During the upwelling season, NE trade winds blow with high frequency and intensity, sea-water temperatures are rather low (for Southern Caribbean conditions), around $21-26{ }^{\circ} \mathrm{C}$, and salinities high (35-38). During the rainy season the trades slack and SW winds are common during storms, and the seas are warmer $\left(27-28{ }^{\circ} \mathrm{C}\right)$, and less saline (30-35) (Márquez, 1982; Ramírez, 1983, 1990; Salzwedel and Müller, 1983; Blanco, 1988; Franco, 2005). 


\section{MATERIALES Y MÉTODOS}

Temperatura, salinidad y nivel del mar

La temperatura y la salinidad de la laguna fueron medidas con un registrador de conductividad HOBO $\AA$ U24002-C (Onset Computer Corporation, Bourne, EE. UU.). El nivel del mar se midió con un registrador $\mathrm{HOBO}{ }^{\circledR}$ U20-0010x-Ti. Cada aparato fue puesto en una carcasa protectora de PVC y ambos se amarraron juntos a un tubo de PVC de 1,9 cm de grosor y $60 \mathrm{~cm}$ de largo (Figura 2A). Para su instalación, el tubo se insertó en una varilla de hierro corrugado de $0,95 \mathrm{~cm}$ de diámetro y $3 \mathrm{~m}$ de largo, que había sido enterrada verticalmente en el fondo; se dejaron aproximadamente $80 \mathrm{~cm}$ libres encima del fondo. La varilla se localizó en el lado interno sombreado de un pequeño muelle de botes en el lado SE de la isla $\left(11^{\circ} 12^{\prime} 32,8^{\prime \prime} \mathrm{N}, 74^{\circ} 13^{\prime} 30,2^{\prime \prime} \mathrm{W}\right)$. Una vez insertado el set de registradores en la varilla, este se amarró a una vareta de acero galvanizado de $12,7 \mathrm{~cm}$ clavada en uno de los pilotes del muelle. El set fue siempre posicionado aproximadamente a la misma profundidad, lo que se logró estableciendo una distancia fija a la plataforma del muelle mediante un metro de costura atado de forma permanente a la carcasa del registrador de nivel. Los registradores fueron recuperados aproximadamente cada dos semanas (tiempo denominado de aquí en adelante como "período de medición"), llevados al laboratorio para lavado, descarga de datos y nueva programación, y luego vueltos a instalar dentro de unas pocas horas o máximo al día siguiente. El intervalo de medición fue de $30 \mathrm{~min}$.

El registrador U24 midió conductividad, que luego fue convertida a salinidad por el programa HOBOWARE® Pro tras el uso de datos de calibración de temperatura y salinidad obtenidos de forma independiente al inicio y al final del período de medición con una sonda portátil precalibrada YSI ${ }^{\circledR} 30$ Pro (YSI Incorporated, Yellow Springs, EE. UU.). El registrador U20 midió presión absoluta, que luego fue convertida a profundidad del agua por el programa tras el uso de una medida real de la altura del agua encima del sensor, tomada con el metro de costura al principio del período de medición. No se tuvieron en cuenta las variaciones en la presión barométrica. Para calcular valores mínimos, promedio y máximos, se usaron series de 13 meses (enero de 2017 a febrero de 2018) de salinidad y temperatura y una serie de un año de nivel del mar (enero de 2017 a enero de 2018). Se calcularon y graficaron promedios diarios de temperatura y salinidad en el tiempo para determinar esquemas estacionales. Se registraron (sin medir la precipitación) los episodios de lluvias en el área de El Rodadero y se superpusieron las fechas sobre las series de promedios diarios de temperatura y salinidad

\section{MATERIALS AND METHODS}

Temperature, salinity and sea-water level

Temperature and salinity of the lagoon were measured with a $\mathrm{HOBO}{ }^{\circledR} \mathrm{U} 24-002-\mathrm{C}$ conductivity logger (Onset Computer Corporation, Bourne, MA, USA). Sea level was recorded with a $\mathrm{HOBO}{ }^{\circledR}$ U20-001-0x-Ti water level logger. Both devices were each placed inside PVC protecting housing, and tied together to a $60 \mathrm{~cm}-$ long, 3/4" PVC tube (Figure 2A). For deployment, the tube was inserted through a $3 / 8$ " corrugated iron rod $(3 \mathrm{~m}$ long) which had been anchored vertically into the bottom (driven with the aid of a small sledge hammer), leaving approximately $80 \mathrm{~cm}$ free above the bottom. The rod was located in the inner, shaded side of a small boat dock on the SE side of the island $\left(11^{\circ} 12^{\prime} 32,8^{\prime \prime} \mathrm{N}, 74^{\circ} 13^{\prime} 30,2^{\prime \prime} \mathrm{W}\right)$. Once inserted, the set was tied to a $5^{\prime \prime}$ galvanized stake driven into one of the dock pilings. The set was always positioned approximately at the same depth, by measuring a fixed distance from the top of the dock platform with a sewing tape which had been tied to the housing of the sea level logger. Loggers were retrieved approximately every two weeks (henceforth called a "measurement period"), brought to the laboratory for cleaning, data retrieval and new programming, and then deployed again within a few hours or the next day at most. Measurement interval was 30 minutes.

The U24 logger measured conductivity, which was then converted to salinity by the HOBOWARE $®$ Pro software using calibration conductivity and temperature data independently obtained at the beginning and the end of the measurement period. This was done with a precalibrated portable YSI ${ }^{\circledR} 30$ Pro probe (YSI Incorporated, Yellow Springs, OH, USA). The U20 logger measured absolute pressure, which was then converted to water depth by the software using actual calibration measurements of water height above the sensor taken at the beginning of the measurement period with the attached sewing tape. Variations in barometric pressure were not taken into account. For analyses, a 13-month series (January 2017 to February 2018) of salinity and temperature, and a 1-year series of sea-level (January 2017-January 2018) were used to calculate minimum, mean and maximum values. Daily means of temperature and salinity were calculated and plotted with time to determine seasonal patterns. Rain episodes in El Rodadero area were recorded (precipitation not measured) and the dates superimposed to the daily mean series of salinity and temperature to 


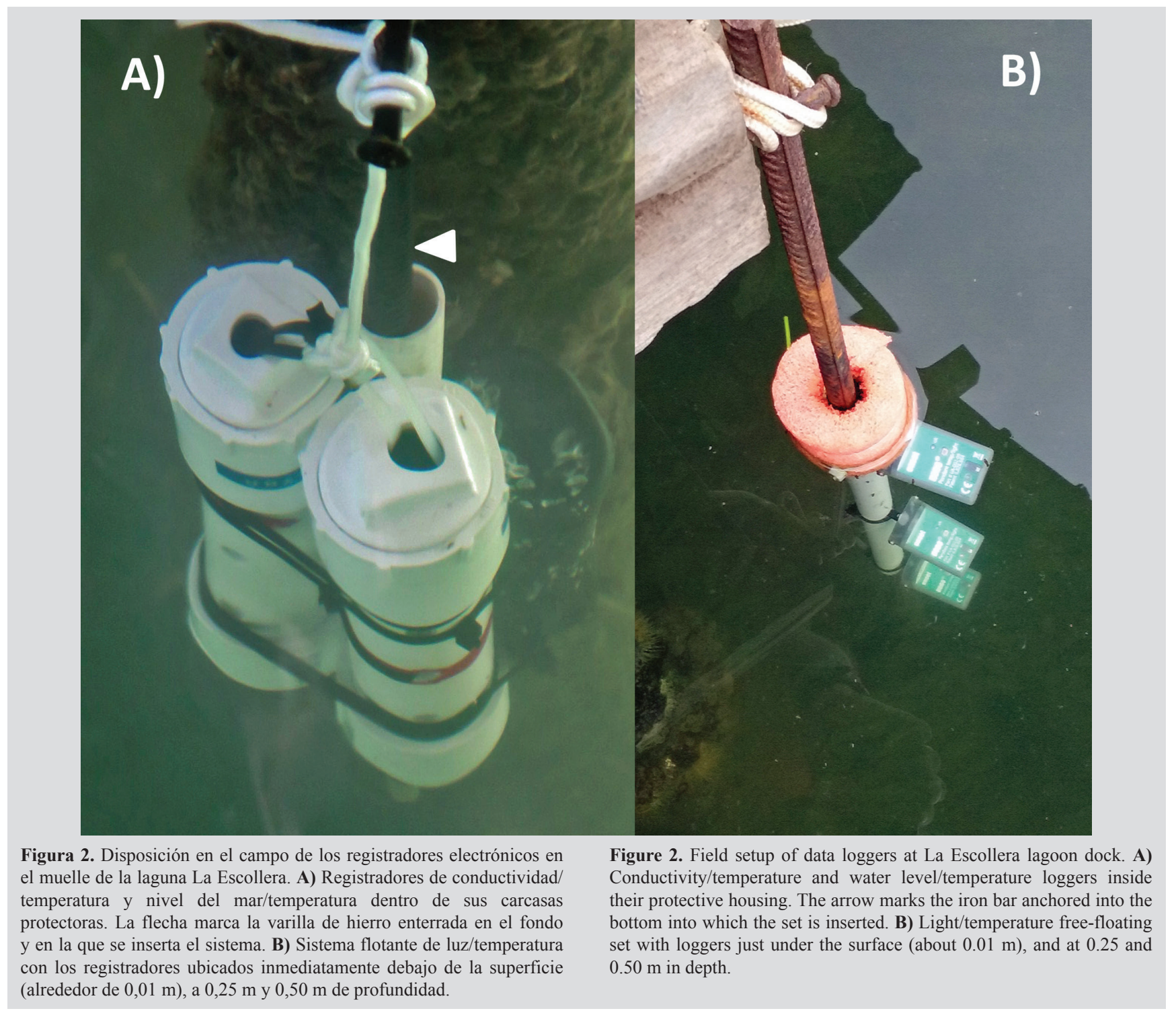

a fin de estudiar gráficamente sus relaciones. Para el nivel del mar, se normalizaron los valores absolutos alrededor del nivel promedio (dato menos promedio) usando el promedio de cada período de medición en lugar del general del año con el fin de evitar el efecto de pequeñas diferencias que hubiesen ocurrido entre períodos en la posición vertical del registrador. Las series de temperatura, salinidad y nivel del mar están disponibles en https://siam.invemar.org.co/documentos-detalle/336649. Para realizar comparaciones particulares, datos de la temperatura del aire y la velocidad del viento fueron tomados cada hora en la estación meteorológica de Punta de Betín en la adyacente bahía de Santa Marta $\left(11^{\circ} 24,585^{\prime}\right.$ N $, 74^{\circ} 21,487^{\prime}$ W), obtenidos del Sistema de Información Ambiental Marina (SIAM) del Instituto de Investigaciones Marinas y Costeras (Invemar) (http://siam.invemar.org.co) y solicitados por medio del enlace http://workflow.invemar.org.co/Forms/accesoadatos. graphically study their relationship. For sea level, absolute values were normalized around the mean level (datum minus mean) but using the mean of each measurement period instead of the overall yearly mean, to account for overlooked small differences between periods in the vertical location of the logger. Temperature, salinity and sea level series are available at https://siam.invemar.org. co/documentos-detalle/336649. For selected comparisons, hourly air temperature and wind velocity data taken at the meteorological station of Punta de Betín in the adjacent Bay of Santa Marta $\left(11^{\circ} 24,5850^{\prime}\right.$ N $, 74^{\circ} 21,4870^{\prime}$ W) were obtained from the Environmental Marine Information System - SIAM of Instituto de Investigaciones Marinas y Costeras - Invemar (http://siam.invemar.org.co), requested through the link http://workflow.invemar.org.co/Forms/ accesoadatos. It should be noted that air temperatures from 
Es importante aclarar que la temperatura del aire de Punta de Betín puede ser representativa para La Escollera, pero los datos de viento deben ser tomados con precaución, ya que Punta de Betín es un promontorio abierto en una península mientras que la laguna está protegida en dos lados por colinas pendientes y además está rodeada de manglares. Los datos de lluvia de Punta de Betín se descartaron porque no siempre coincidieron con los episodios de lluvia registrados para El Rodadero.

Durante la recuperación y postura de los registradores, también se midió la distribución vertical de salinidad y temperatura en el primer metro de profundidad (cada 0,20 m) con el sensor YSI. La profundidad se midió con una cuerda metrada amarrada al cable del sensor. Estos datos se graficaron para comparar la estratificación de la columna de agua entre las épocas seca y de lluvia y para inferir mezclas luego de fuertes episodios de lluvia. En algunos casos, se calculó el perfil vertical de la salinidad como sigma-t $(\sigma t)$ a partir de valores de salinidad (S) y temperatura (T), usando la ecuación de estado del agua de mar a la presión de la superficie, donde $\sigma \mathrm{t}=\rho(\mathrm{T}$; S) - 1000. La ecuación fue resuelta mediante los algoritmos de Fofonoff y Millard Jr. (1983) a través de un calculador disponible en la web (https://www.mt-oceanography.info/ Utilities/density.html).

Intensidad de luz y temperatura en la columna de agua

La distribución vertical de la temperatura y la extinción de la luz en la columna de agua (como una medida de la transparencia y la luz disponible para la producción primaria) se midieron amarrando tres registradores $\mathrm{HOBO} \otimes$ PendantUA-002-08 Temp/Light a un tubo de PVC de $19 \mathrm{~cm}$ de diámetro y $0,60 \mathrm{~m}$ de largo, el cual tenía un anillo flotante en un extremo (Figura 2B). El tubo se insertó en una varilla de $3 \mathrm{~m}$ de largo que se había enterrado en el fondo blando, pero que, en este caso, estaba ubicada en una esquina no sombreada del muelle y con una porción por encima del agua. Los registradores se amarraron de tal manera que el primero quedó ubicado cerca de $0,01 \mathrm{~m}$ bajo el agua (de aquí en adelante llamado "en superficie"), el segundo a $0,25 \mathrm{~m}$ y el tercero a $0,50 \mathrm{~m}$ de profundidad. La flotación libre permitió medir a la profundidad fija con independencia del nivel del mar. La recuperación y postura se llevó a cabo simultáneamente con los otros registradores. Se analizó un año de datos (de marzo de 2017 a marzo de 2018). La temperatura se usó para estudiar la variación vertical diurna con las épocas climáticas. Para la luz, solo se usaron datos de alrededor del mediodía (10:00-13:30, un caso entre las 14:00-15:00) y de los primeros 1-3 días luego de la postura, en los cuales los registradores estaban todavía limpios de sedimentos e incrustaciones (73 días en total). Con
Punta de Betín may be representative for La Escollera, but wind data must be used with caution as Punta de Betín is an open promontory in a peninsula, and the lagoon is protected from two sides by steep hills and also surrounded by mangroves. Rainfall data were discarded as they did not always coincide with the rainfall episodes recorded for El Rodadero.

During retrieval and deployment of loggers, the vertical distribution of salinity and temperature was also measured within the first meter of depth (every $20 \mathrm{~cm}$ ), with the YSI probe; depth was measured from a metered rope tied to the sensor cable. These data were plotted to compare water column stratification between the dry and rainy seasons, and to infer water mixing after heavy rain episodes. In some cases, the vertical profile of sea-water density was calculated as sigma-t $(\sigma t)$ from salinity $(S)$ and temperature ( $\mathrm{T})$, values using the Equation of State for sea water at surface pressure, where $\sigma \mathrm{t}=\rho(\mathrm{T} ; \mathrm{S})-1000$, solved according to the algorithms of Fofonoff and Millard Jr. (1983), through a calculator available on the web (https:// www.mt-oceanography.info/Utilities/density.html).

Light intensity and temperature in the water column

Vertical distribution of temperature and extinction of light in the water column (for a measure of transparency and of light available for primary production) was measured by tying three $\mathrm{HOBO}{ }^{\circledR}$ PendantUA-002-08 Temp/Light loggers to a $0.60 \mathrm{~m}$-long, $3 / 4$ " PVC pipe, which had a floater ring on one side (Figure 2B). The pipe was then inserted into another $3 \mathrm{~m}$-long iron rod that had been anchored into the soft bottom, but in this case situated in a non-shaded corner of the dock and having a portion above water. Loggers were tied so that one was placed about $0.01 \mathrm{~m}$ below the surface (thenceforth to be called "surface"), another at $0.25 \mathrm{~cm}$ and the third at $0.50 \mathrm{~m}$ in depth. The free flotation allowed for the measurement of light penetration regardless of sea level. Retrieval and deployment was carried out simultaneously with the other loggers. One-year data from March 2017 to March 2018 were analyzed. Temperature data were used to study diurnal vertical variation. For light extinction, only data around noon (10:00-13:30, one case 14:00-15:00) were used, from the first 1-3 days after deployment in which the loggers were still clean of sediments and fouling (73 days total). With these data, the light extinction coefficient $k$ was calculated for each day from the Beer-Lambert equation $\left(I_{Z}=I_{0} \mathrm{e}^{-k Z}\right.$, Parsons et al., 1984), by regression of light intensity with depth, linearizing the equation to: 
estos datos, se calculó el coeficiente de extinción de la luz $k$ para cada día usando la ecuación de Beer-Lambert $\left(I_{Z}=I_{0} \mathrm{e}^{-k Z}\right.$, Parsons et al., 1984) mediante regresión de la intensidad de luz con la profundidad, con lo cual se volvió lineal la ecuación, así:

$$
\ln I_{Z}=-k Z+\ln I_{0}
$$

Donde:

$I_{Z}=$ intensidad de luz a cierta profundidad

$k=$ coeficiente de extinción (pendiente de la línea)

$\mathrm{Z}=$ profundidad

$I_{0}=$ intensidad de luz en la superficie (intercepto de la línea a $\mathrm{Z}=0$ )

Las regresiones se realizaron de forma separada para cada día tomando las medidas disponibles (cada $30 \mathrm{~min}$ alrededor del mediodía) como réplicas. Los coeficientes de extinción fueron comparados entre estaciones. A partir de los valores mínimo, promedio y máximo del coeficiente de extinción y de las intensidades de luz incidente en superficie, se graficó la disminución de la luz con la profundidad y se calculó la profundidad, en la que la luz era $1 \%$.

\section{RESULTADOS}

\section{Variación entre épocas}

Series de tiempo. Las aguas de la laguna La Escollera fueron, en promedio, cálidas $\left(30,7^{\circ} \mathrm{C}\right)$ y salinas $(34,3)$ (Tabla 1$)$. Las temperaturas y salinidades del agua siguieron el esquema climático local de una época fría y seca con afloramiento y otra cálida y lluviosa (Figura 3). De mediados de diciembre a principios de abril, la laguna tuvo temperaturas menores a $30{ }^{\circ} \mathrm{C}$, las cuales cayeron a un mínimo de $24,6{ }^{\circ} \mathrm{C}$ a mitad de enero, en conjunto con la época regional de afloramiento marino y el ligero enfriamiento de la atmósfera durante el invierno del hemisferio norte (llegando hasta $23,1^{\circ} \mathrm{C}$ ). El resto del año, las temperaturas del aire y de la laguna se mantuvieron más altas (alcanzaron $34,7^{\circ} \mathrm{C}$ y $35,0^{\circ} \mathrm{C}$, respectivamente). Las salinidades fueron regularmente más altas en la época seca (>35) e intermitentemente más bajas en la época de lluvia, en asociación ajustada con las lluvias y escorrentías locales. De hecho, de mediados de septiembre a finales de noviembre, las salinidades cayeron debajo de 30 luego de fuertes aguaceros hasta llegar a 15,1 luego de una semana de lluvias sostenidas a mediados de noviembre (Figura 3). Las velocidades del viento en la bahía de Santa Marta fueron altas en la época seca: los vientos alisios soplaron con una velocidad promedio y máxima de $6,5 \mathrm{~m} \mathrm{~s}^{-1}$ y $18,6 \mathrm{~m} \mathrm{~s}^{-1}$, respectivamente. Mientras tanto, para el resto del año, la velocidad del viento estuvo alrededor de 3,8 $\mathrm{m} \mathrm{s}^{-1}$ y la máxima velocidad no excedió $15 \mathrm{~m} \mathrm{~s}^{-1}$ (Figura 3).

$$
\ln I_{Z}=-k Z+\ln I_{0}
$$

Where:

$I_{Z}=$ light intensity at a given depth

$k=$ extinction coefficient (slope of the line)

$\mathrm{Z}=$ depth

$I_{0}=$ light intensity on the surface (intercept of the line at $\mathrm{Z}=0$ )

Regressions were carried out separately for each day, taking the available (every 30 minutes around noon) vertical measurements as replicates. From the minimum, mean and maximum extinction coefficients and the incident light intensities at the surface, the decrease of light with depth was plotted, and the depth for $1 \%$ light intensity calculated.

\section{RESULTS}

\section{Seasonal variation}

Time series. La Escollera lagoon waters were on average warm $\left(30.7^{\circ} \mathrm{C}\right)$ and saline (34.3) (Table 1). Sea-water temperatures and salinities followed the local seasonal pattern of dry-upwelling cool and rainy-warm periods (Figure 3). From middle December to early April, the lagoon had temperatures lower than $30{ }^{\circ} \mathrm{C}$, dropping to a minimum of $24.6{ }^{\circ} \mathrm{C}$ in middle January, in association with the regional marine upwelling season and the overall slight cooling of the atmosphere during the northern hemisphere winter (down to $23.1{ }^{\circ} \mathrm{C}$ ). For the rest of the year lagoon and air temperatures remained higher, topping respectively $34.7^{\circ} \mathrm{C}$ and $35,0^{\circ} \mathrm{C}$. Salinities were regularly higher $(>35$ ) during the dry season, and intermittently lower during the rainy season, in close association with local runoff from rainfall. Indeed, from middle September to late November salinities dipped below 30 after heavy downpours, reaching 15.1 after about a week of sustained rains in middle November (Figure 3). Wind speeds in the Bay of Santa Marta were high in the dry season, the trade winds blowing with mean and maximum speeds respectively $6.5 \mathrm{~m} \mathrm{~s}^{-1}$ and $18.6 \mathrm{~m} \mathrm{~s}^{-1}$, while for the rest of the year mean wind speed was around $3.8 \mathrm{~m} \mathrm{~s}^{-1}$ and maximum speed did not exceed $15 \mathrm{~m} \mathrm{~s}^{-1}$ (Figure 3).

Vertical profiles. Single-point measurements of salinity and temperature in the vertical profile (0 to $1 \mathrm{~m}$ in depth, every $20 \mathrm{~cm}$ ) taken approximately every two weeks with a handheld sensor, allowed for the comparison of the 
Tabla 1. Variación general en salinidad, temperatura del agua y nivel del mar en la laguna La Escollera, y de temperatura del aire y velocidad del viento en Punta de Betín (bahía de Santa Marta), de enero de 2017 a marzo de 2018. Valores calculados directamente de todas las mediciones (intervalos de 30 minutos para las variables del agua y de 1 hora para las atmosféricas).
Table 1. Overall variation in sea-water temperature, salinity and sea level at La Escollera lagoon, and in air temperature and wind speed at Punta de Betín (Bay of Santa Marta). Data from January 2017 to February 2018. Values calculated directly from all measurements (30 minutes' intervals for sea-water variables and hourly intervals for atmospheric variables).

\begin{tabular}{|c|c|c|c|c|}
\hline Variable & Promedio/Mean & Máximo/Maximum & Mínimo/Minimum & $\begin{array}{l}\text { Desviación estándar/ } \\
\text { Standard deviation }\end{array}$ \\
\hline Salinidad/Salinity (PSU) & 34.3 & 38.9 & 15.1 & 2.8 \\
\hline Temperatura/Temperature $\left({ }^{\circ} \mathrm{C}\right)$ & 30.7 & 34.7 & 24.6 & 2.0 \\
\hline Nivel del mar relativo/Relative sea level (m) & 0.0 & -0.31 & +0.37 & Range 0.68 \\
\hline Temperatura del aire/Air temperature $\left({ }^{\circ} \mathrm{C}\right)$ & 28.7 & 35.0 & 22.7 & 1.9 \\
\hline Velocidad del viento/Wind speed $\left(\mathrm{m} \mathrm{s}^{-1}\right)$ & 4.71 & 18.6 & 0.0 & 3.1 \\
\hline
\end{tabular}

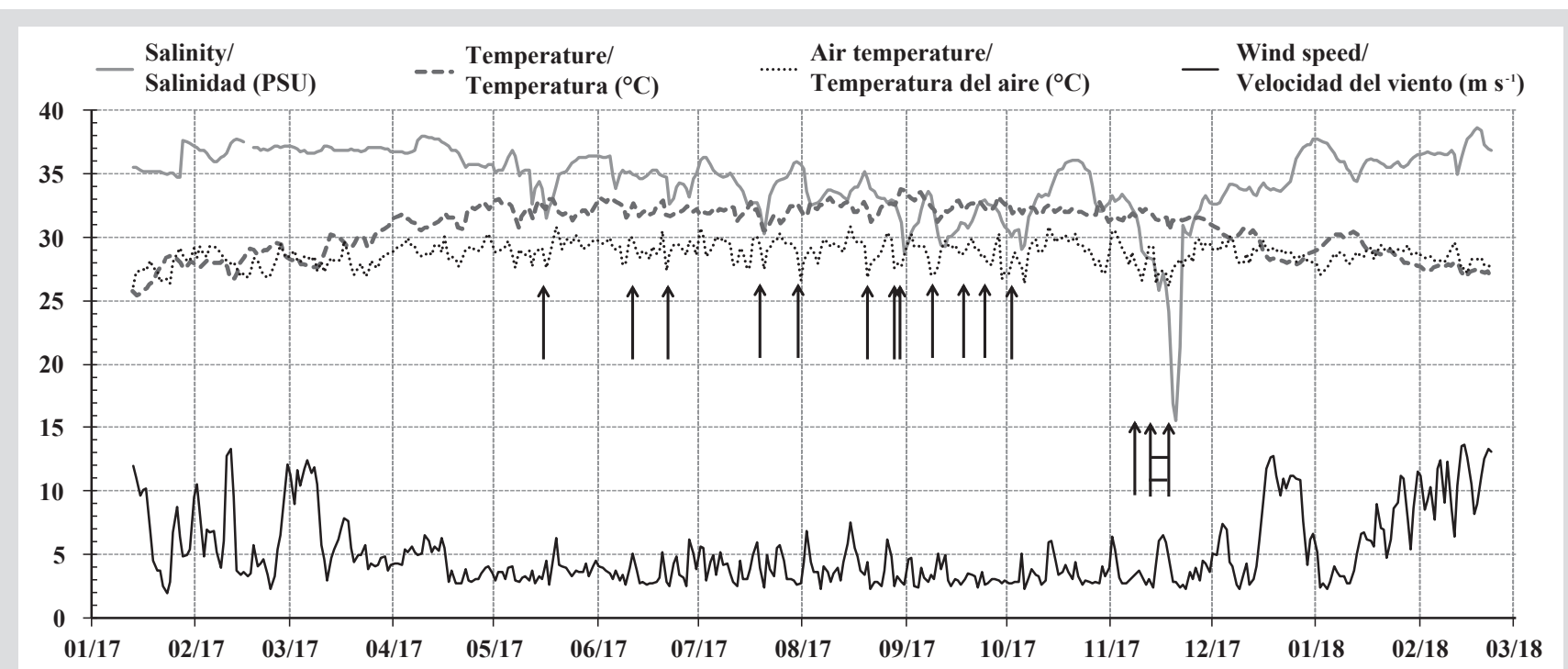

Figura 3. Valores promedio diarios de salinidad y temperatura del agua en la laguna La Escollera y de temperatura y velocidad del viento en Punta de Betín (bahía de Santa Marta), de enero de 2017 a febrero de 2018. Las flechas marcan registros de lluvia (chubascos y aguaceros, no medidos). Las dos flechas de la derecha, unidas por barras horizontales, indican una semana de lluvias repetidas (13-18 noviembre).
Figure 3. Daily mean values for La Escollera lagoon sea-water salinity and temperature, and for Punta de Betín (Bay of Santa Marta) air temperature and wind speed, from January 2017 to February 2018. Arrows mark recorded occurrence of rainfall (showers and downpours, not measured); rightmost two arrows joined by horizontal lines depict a week of repeated rains (13-18 November).
Perfiles verticales. Mediciones puntuales de salinidad y temperatura en el perfil vertical (de 0 a $1 \mathrm{~m}$ de profundidad cada $0,20 \mathrm{~m}$ ), efectuadas aproximadamente cada dos semanas con un sensor de mano, permitieron comparar la estructura vertical de la columna de agua alrededor del mediodía entre las épocas seca y de lluvia (Figura 4). En general, en las dos épocas secas cubiertas por los datos (eneroabril de 2017, diciembre de 2017-febrero de 2018) la columna de agua estuvo bien mezclada mientras que en la época de lluvia (mayo-noviembre de 2017) la columna de agua estuvo en general mezclada, pero se estratificó, con bajas salinidades en superficie, luego de episodios de lluvia. Como un ejemplo de la época seca, los datos verticales al mediodía del 13 de enero al 17 de abril (Figura 4, recuadro A) muestran tanto vertical structure of the water column around noon between the dry and rainy seasons (Figure 4). Overall, during both dry season periods covered by the data (January-April 2017, December 2017-February 2018), the water column was well mixed, while during the rainy season (MayNovember 2017) the water column was generally mixed but became stratified, with lower salinities at the surface, after rainfall episodes. As an example of the dry season, vertical data around noon from January 13 to April 7 (Figure 4, box A) show that salinity was high $(\geq 35)$ and the water column well mixed and temperature was cool $\left(<29{ }^{\circ} \mathrm{C}\right)$, with moments of colder $\left(26{ }^{\circ} \mathrm{C}\right)$ conditions. In contrast, two days after the first heavy rainfall of the 2017 rainy season, which took place on May 16, the water 


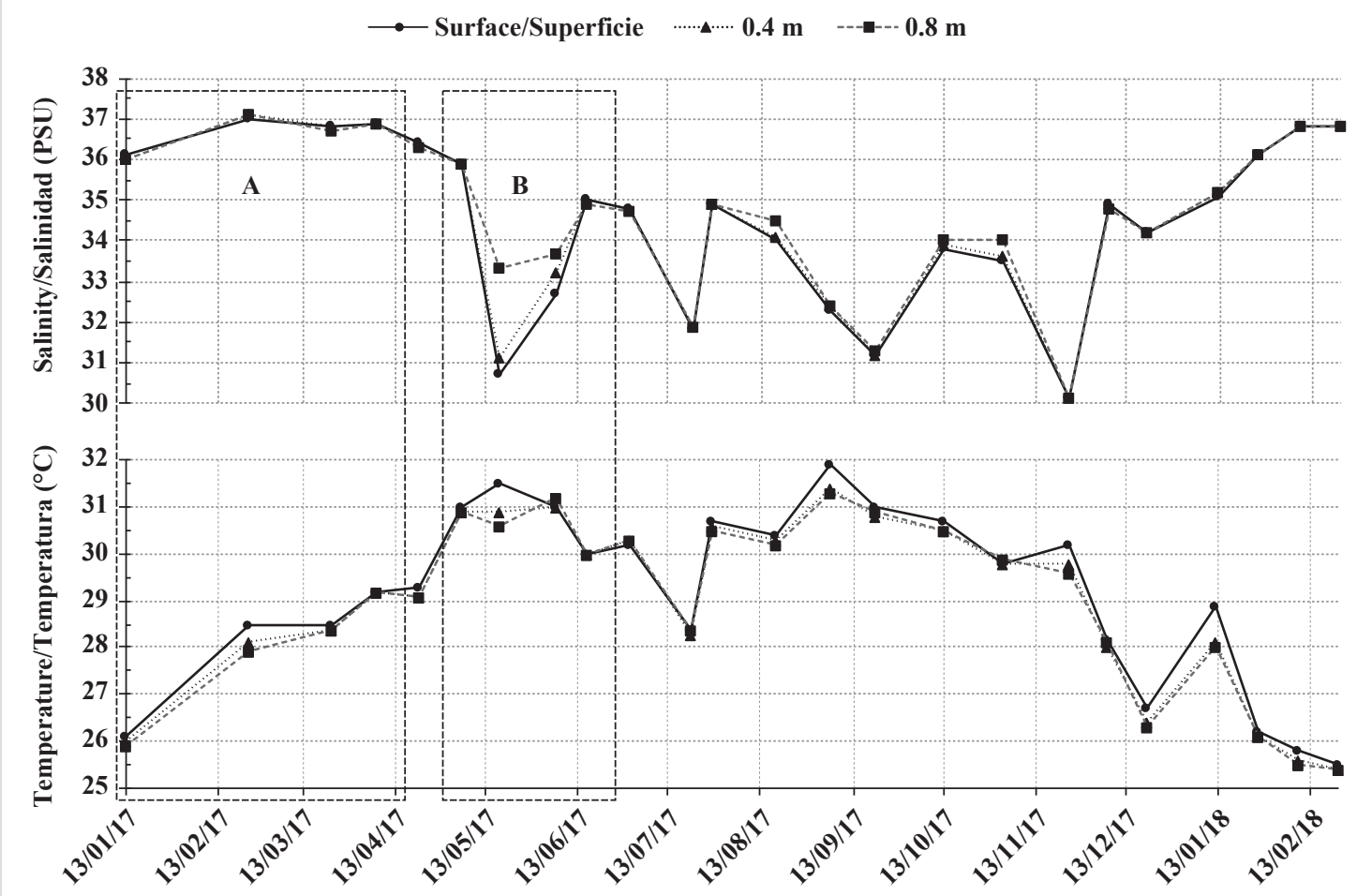

A

Salinity/Salinidad (PSU)

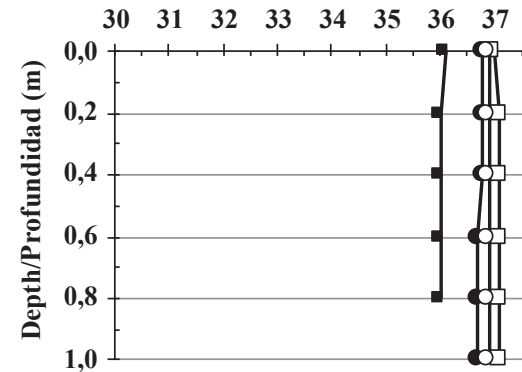

Temperature/Temperatura $\left({ }^{\circ} \mathrm{C}\right)$

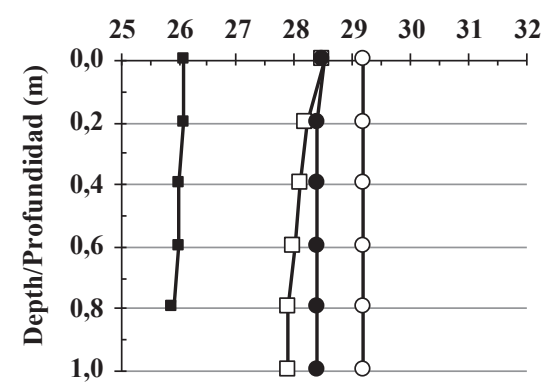

Figura 4. Distribución vertical de salinidad y temperatura en la laguna La Escollera de enero de 2017 a febrero de 2018. Datos tomados aproximadamente cada dos semanas alrededor del mediodía (10:2013:00) con un sensor de mano, de 0 a $1 \mathrm{~m}$ de profundidad cada $0,20 \mathrm{~m}$. Los datos en superficie, $0,4 \mathrm{~m}$ y $0,8 \mathrm{~m}$ se presentan en los dos paneles superiores. Perfiles completos de profundidad marcados en los recuadros A y B se muestran en los paneles inferiores.

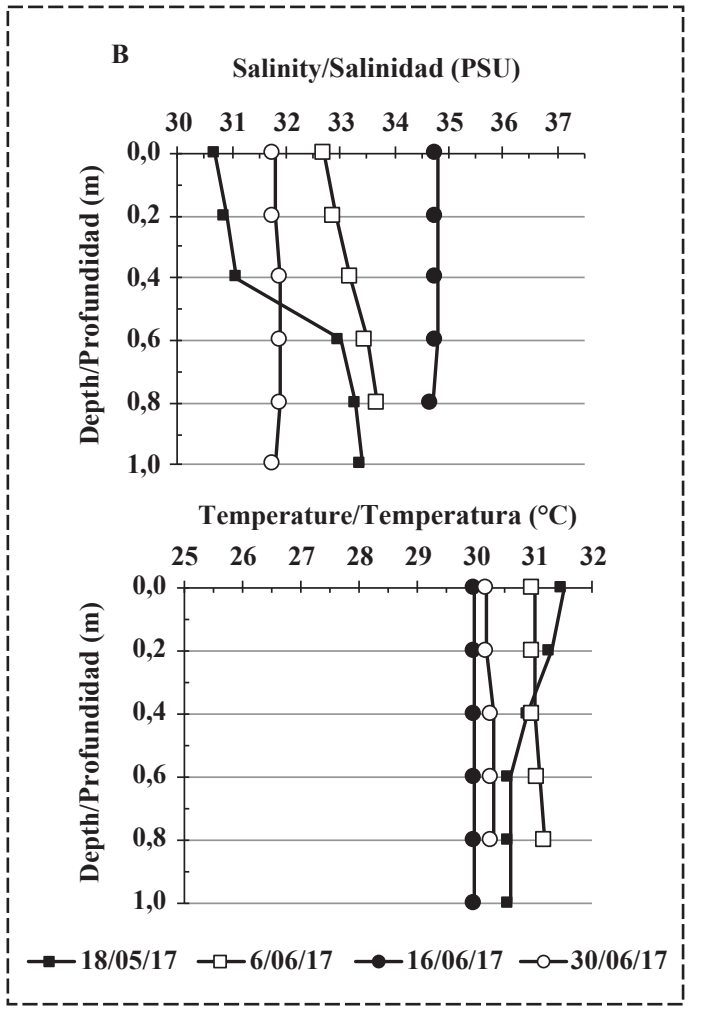

Figure 4. Vertical distribution of salinity and temperature at La Escollera lagoon from January 2017 to February 2018. Data taken approximately every two weeks around noon (10:20-13:00) with a handheld sensor, every $20 \mathrm{~cm}$ in depth from the surface to $1 \mathrm{~m}$. Data for the surface, $0.4 \mathrm{~m}$ and $0.8 \mathrm{~m}$ are presented in the two upper panels. Complete depth profiles for the periods marked in boxes A and B are depicted in the lower panels. 
la salinidad alta $(\geq 35)$ y la columna de agua bien mezclada como la temperatura fresca $\left(<29^{\circ} \mathrm{C}\right)$, con momentos de condiciones más frías $\left(26^{\circ} \mathrm{C}\right)$. En contraste, dos días luego del primer aguacero fuerte de la época de lluvia de 2017, que ocurrió el 16 de mayo, la columna de agua estaba todavía estratificada (18 de mayo, recuadro B), con salinidades menores en los primeros $0,4 \mathrm{~m}$. La columna de agua estuvo bien mezclada de ahí en adelante (6-30 de junio, recuadro B), aunque menos salina $(<34-35)$ y más caliente $\left(>29^{\circ} \mathrm{C}\right)$ que en la época seca.

\section{Variación diaria}

Nivel del mar. La oscilación del nivel del mar en La Escollera está claramente dominada por la marea, ya que sigue el esquema astronómico mixto del mar Caribe, con dos altas y dos bajas por día, pero de diferente altura, habiendo períodos de mareas vivas (de sicigia) y muertas (de cuadratura) (Figura 5). Dentro de un ciclo lunar dado, a medida que los días avanzan, una de las altas diarias se vuelve más pequeña mientras que la otra incrementa, cambiando de lugar eventualmente en un esquema complejo; en un momento, una de las dos desaparece por uno o dos días (Figura 5). El nivel del mar relativo de un año de mediciones (13 de enero de 2017-13 de enero de 2018) varió entre $-0,31 \mathrm{~m} \mathrm{y}+0,37 \mathrm{~m}$, siendo el intervalo máximo de $0,68 \mathrm{~m}$ (Tabla 1). Para el período de 28 días mostrado en la Figura 5, el nivel relativo del mar varió entre $-0,23 \mathrm{y}+0,27 \mathrm{~m}$, siendo el máximo intervalo de $0,50 \mathrm{~m}$. El cambio de nivel del mar entre altas y bajas varió entre 0,04 y $0,44 \mathrm{~m}$, con un column was still stratified (May 18, box B), with lower salinities on the upper $0.4 \mathrm{~m}$. The water column was wellmixed thereafter (June 6-30, box B), although less saline $(<34-35)$ and warmer $\left(>29^{\circ} \mathrm{C}\right)$ than during the dry-season.

\section{Daily variation}

Sea level and tides. The sea level oscillation at $\mathrm{La}$ Escollera is clearly dominated by the tide, as it follows the mixed astronomical tide pattern of the Caribbean Sea, with two high and lows per day but of different height, there being periods of spring and neap tides (Figure 5). Within a given lunar cycle, as the days proceed and the tide lags about an hour every day, one of the daily highs becomes smaller, while the other high increases, eventually exchanging places in a complex pattern; at some point one of the two may disappear for a day or two (Figure 5). Relative sea level of one year of measurements, from January 13, 2017 to January 13,2018 , varied between $-0.31 \mathrm{~m}$ and +0.37 $\mathrm{m}$, the maximal range being $0.68 \mathrm{~m}$ (Table 1). For the exemplified 28-day period depicted in Figure 5, relative sea level varied between -0.23 and 0.27 , the maximal range being $0.50 \mathrm{~m}$. Sea level change between highs and lows varied between $0.04 \mathrm{~m}$ and $0.44 \mathrm{~m}$, with a mean tidal change of $0.19 \mathrm{~m}$. Detailed analysis and decomposition of the tide (astronomical and meteorological components) is being carried out in a separate study.

Seasonal patterns of daily variation. Figures 6 to 8 depict example weekly intervals of daily variation in

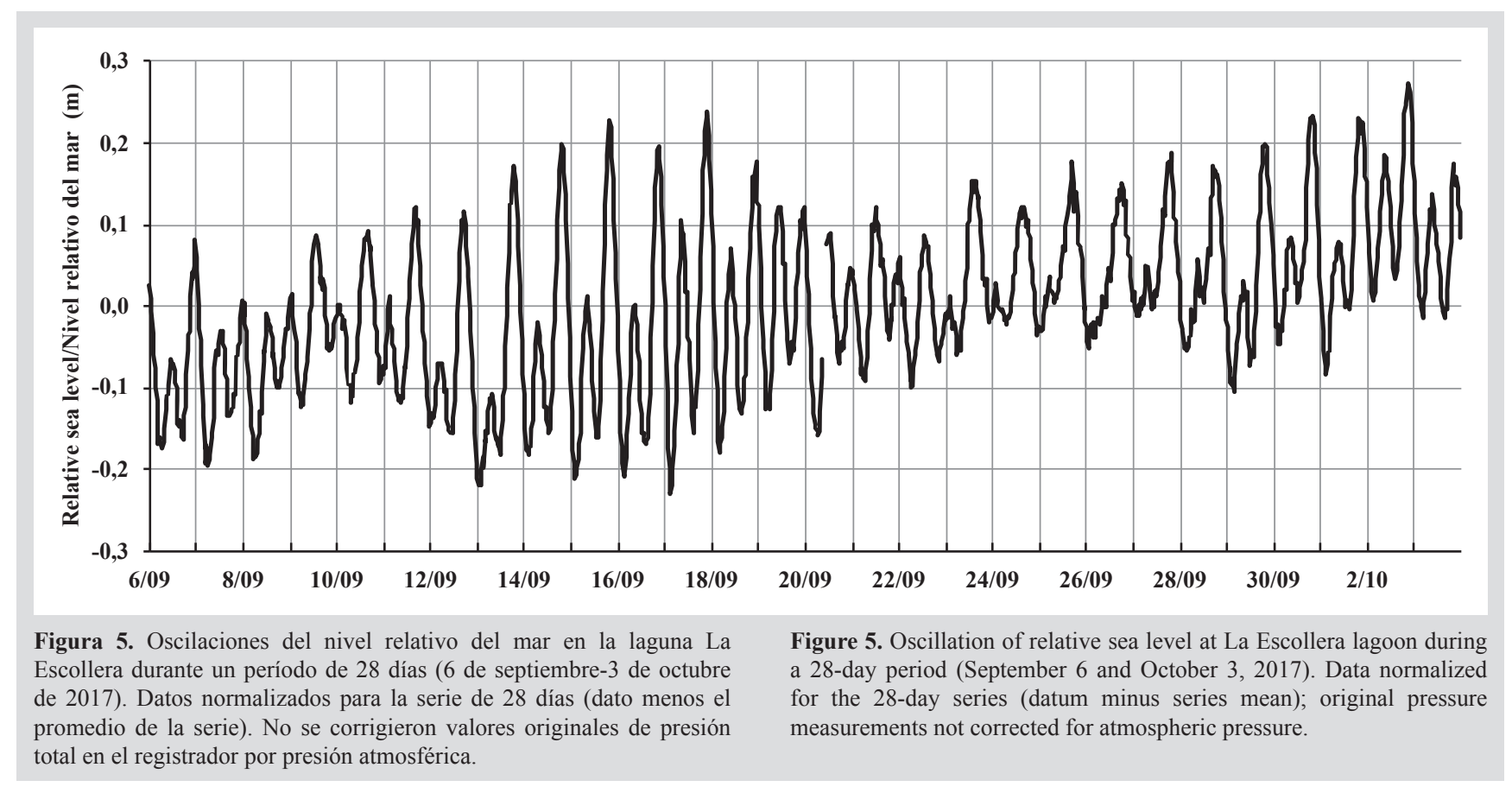


promedio de cambio mareal de $0,19 \mathrm{~m}$. Un análisis detallado y la descomposición de la marea (componentes astronómico y meteorológico) se está llevando a cabo en un estudio separado.

Esquemas estacionales de variación diaria. Las figuras 6 a 8 muestran ejemplos de intervalos semanales de variación diaria en la salinidad, temperatura y nivel del mar en la laguna La Escollera, y en la temperatura del aire y la velocidad del viento en Punta de Betín (bahía de Santa Marta). La temperatura del agua fue medida en superficie, a $0,25 \mathrm{~m}$ y a $0,50 \mathrm{~m}$ de profundidad con los registradores flotantes. El primer intervalo, 22-29 de abril de 2019 (Figura 6), corresponde al final de la época seca, cuando los fuertes vientos alisios que inducen afloramiento disminuyen. Las salinidades permanecieron altas pero estables y las
La Escollera lagoon sea-water salinity, temperature and sea level, and Punta de Betín (Bay of Santa Marta) air temperature and wind speed. The sea-water temperature was measured at the surface, $0.25 \mathrm{~m}$ and $0.50 \mathrm{~m}$ with the floating loggers. The first interval, April 22-29, 2017 (Figure 6), corresponds to the end of the dry season, when the strong upwelling-inducing trade winds had slacked, salinity remained high but stable, and temperatures were relatively high and followed a daily cycle of day warming and night cooling, warming being slightly greater at the surface of the lagoon than further deeper, the water column cooling uniformly throughout the night. Winds seemed to follow a rather regular pattern of late afternoon intensification. Daily sea level variation, with its 1-hour
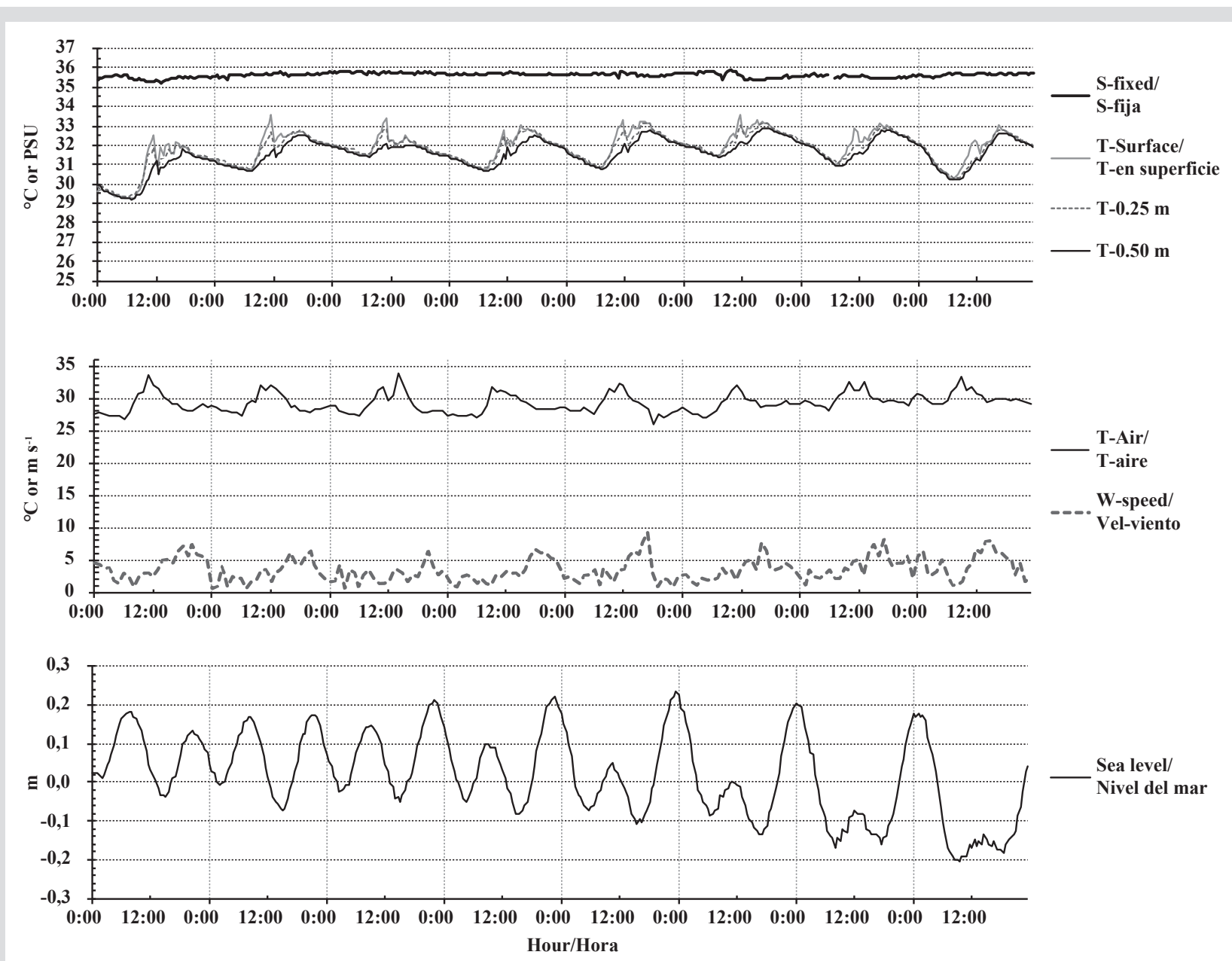

Figura 6. Variación diaria en salinidad (S-fija), temperatura del agua (T-en superficie, $0,25 \mathrm{~m}$ y $0,50 \mathrm{~m}$ de profundidad) y nivel del mar en la laguna de La Escollera, y de temperatura del aire (T-aire) y velocidad del viento (Vel-viento) en Punta de Betín (bahía de Santa Marta), del 22 al 29 de abril de 2017. Intervalo de medida de 30 minutos para el agua y de 1 hora para el aire. Los registradores de temperatura flotaron con la marea y medían así a las mismas profundidades mientras que el registrador de conductividad tenía una posición fija y, por lo tanto, cambió de profundidad con la marea.
Figure 6. Daily variation of La Escollera lagoon sea-water salinity (S-fixed), temperature (T-at the surface, $0.25 \mathrm{~m}$ and $0.5 \mathrm{~m}$ in depth) and sea level, and of Punta de Betín (Bay of Santa Marta) air temperature (T-air) and wind speed (W-speed), from April 22 to 29, 2017. Measurement intervals of 30 minutes for sea-water and 1 hour for air. Temperature loggers floated with the tide, thus measuring at the same depths, while the conductivity logger had a fixed position and thus changed depth as the tide changed. 
temperaturas fueron relativamente altas y siguieron el ciclo diario de calentamiento en el día y de enfriamiento en la noche. El calentamiento fue ligeramente mayor en la superficie de la laguna que en lo profundo y la columna de agua se enfrió uniformemente en la noche. Los vientos parecieron seguir un patrón algo regular de intensificación en la tarde. La variación diaria del nivel del mar, con su retraso diario de una hora, no pareció relacionarse directamente con las variaciones en la temperatura del agua.

El segundo intervalo, 6-13 de septiembre de 2017 (Figura 7), corresponde a la época de lluvia, con un episodio de fuerte lluvia en la tarde del 8 de septiembre (flecha). En general, la salinidad se mantuvo debajo de 34 y poco a poco se volvió menor. Curiosamente, hubo pulsos cortos de menores salinidades, de hasta 3 unidades, no asociados directamente daily delay in the oscillations, did not seem to relate directly to the variations in sea-water temperature.

The second interval, September 6-13, 2017 (Figure 7), corresponds to the rainy season, with one episode of heavy rainfall on the afternoon of September 8 (arrow). Overall, salinity remained below 34 , becoming progressively lower. Interestingly, there were short pulses of lower salinity, down to 3 units, not directly associated with rainfall, which may reflect circulation of less saline masses that move throughout the lagoon. Sea-water and air temperatures remained high with the regular day warming and night cooling. However, after the rainfall of Sept 8 , there was additional cooling, especially overnight at the surface (and in the air), that soon became generalized for the entire water column and made the next two days
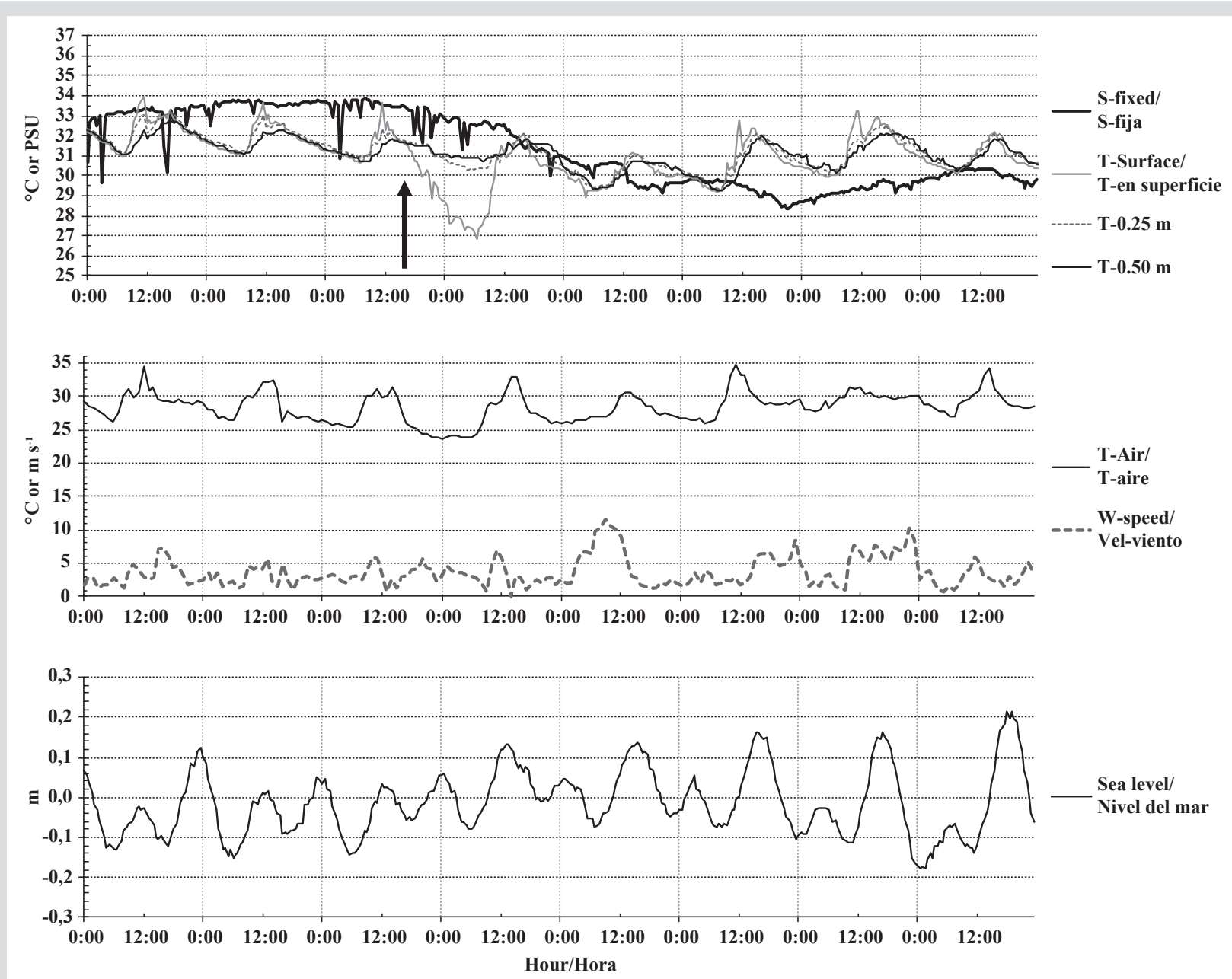

Figura 7. Variación diaria en salinidad (S-fija), temperatura del agua (T-en superficie, $0,25 \mathrm{~m}$ y $0,50 \mathrm{~m}$ de profundidad) y nivel del mar en la laguna de La Escollera, y de temperatura del aire (T-aire) y velocidad del viento (Velviento) en Punta de Betín (bahía de Santa Marta), del 6 al 13 de septiembre de 2017. Condiciones de medición como en la Figura 6. La flecha marca el inicio de un episodio de fuerte lluvia (8 de septiembre, 16:00).
Figure 7. Daily variation of La Escollera lagoon sea-water salinity (S-fixed), temperature (T-at the surface, $0.25 \mathrm{~m}$ and $0.5 \mathrm{~m}$ in depth) and sea level, and of Punta de Betín (Bay of Santa Marta) air temperature (T-air) and wind speed (W-speed), from September 6 to 13, 2017. Measurement conditions as in Figure 6. The arrow marks the beginning of a heavy rainfall episode (September 8, 16:00). 
con lluvias, que pueden reflejar la circulación de masas de agua menos salinas en la laguna. Las temperaturas del agua y del aire se mantuvieron altas con la regularidad del calentamiento en el día y de enfriamiento en la noche. Sin embargo, luego de la lluvia del 8 de septiembre, hubo enfriamiento adicional, especialmente en la noche, en superficie (y en el aire). Ese enfriamiento pronto recubrió toda la columna de agua e hizo que los dos días siguientes fueran más fríos, debido posiblemente a un incremento en la velocidad del viento y a la nubosidad generalizada (no medida). Las variaciones diarias del nivel del mar no parecieron relacionadas directamente ni con los pulsos de baja salinidad ni con el enfriamiento o calentamiento luego de la lluvia.

El tercer intervalo, 13-20 de enero de 2018 (Figura 8), corresponde a la época seca, con alta salinidad (sobre 34 cooler, possibly owing to an increase in the wind speed and a generalized cloud cover (not measured). Daily sea level variation did not look directly related to either the low salinity pulses or to cooling and warming after the rain episode.

The third interval, January 13-20, 2018 (Figure 8), corresponds to the dry season, with high salinity (above 34 and higher than 36), and lower sea-water temperatures (mostly below $30^{\circ} \mathrm{C}$ even around noon). Air temperatures were generally lower than in April 2017, not warming as much around noon on most days. Winds reached higher speeds than in the other intervals. In contrast, overnight cooling of the lagoon surface occurred every day and was quite important, being 3-6 ${ }^{\circ} \mathrm{C}$ lower in the early morning than around noon. However, there were point
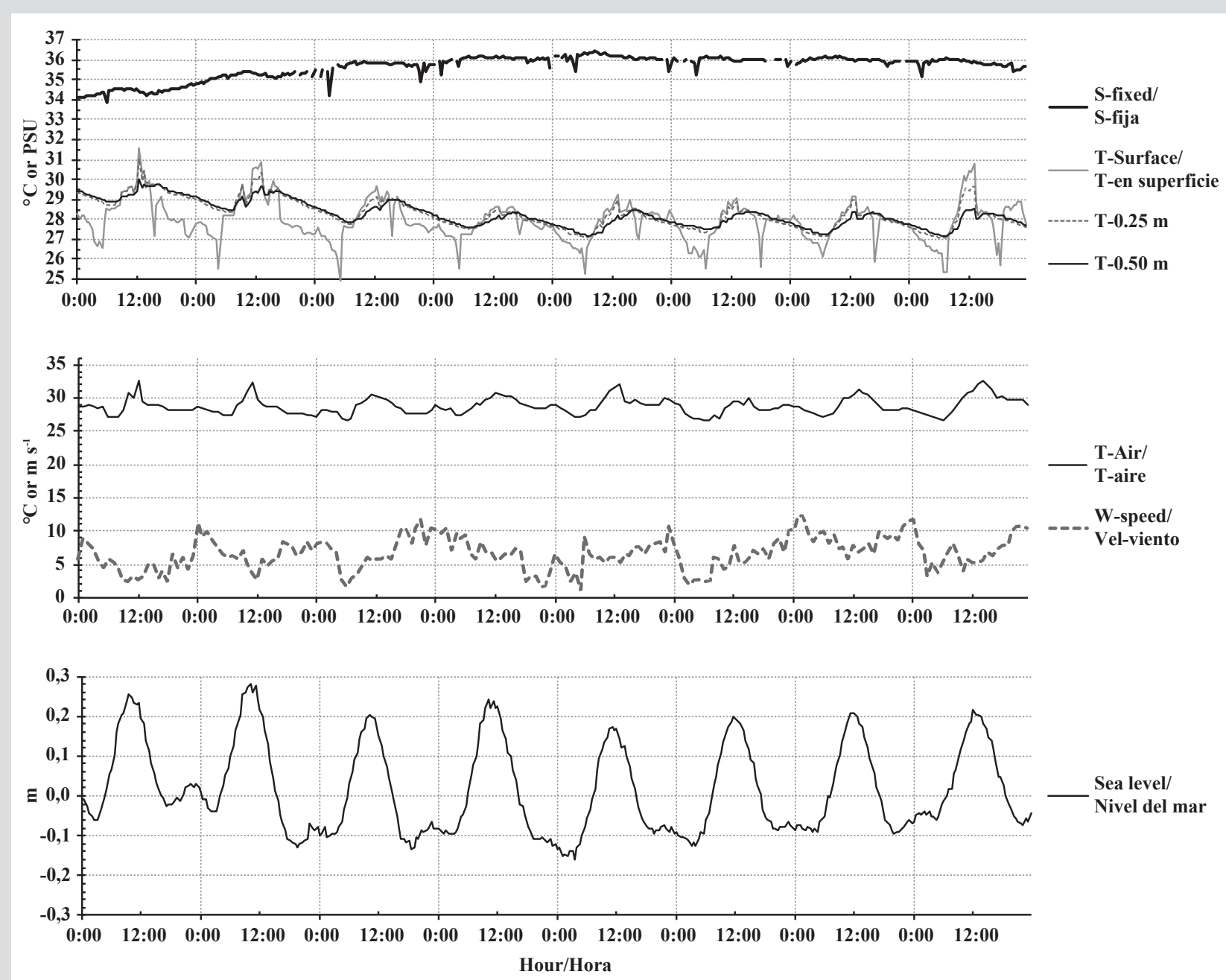

Figura 8. Variación diaria en salinidad (S-fija) y temperatura del agua (T-en superficie, $0.25 \mathrm{~m}$ y $0.50 \mathrm{~m}$ de profundidad) y nivel del mar en la laguna de La Escollera, y de temperatura del aire (T-aire) y velocidad del viento (Vel-viento) en Punta de Betín (bahía de Santa Marta), del 13 al 20 de enero de 2018. Condiciones de medición como en la Figura 6.
Figure 8. Daily variation of La Escollera lagoon sea-water salinity (S-fixed), temperature (T-at the surface, $0.25 \mathrm{~m}$ and $0.5 \mathrm{~m}$ in depth) and sea level, and of Punta de Betín (Bay of Santa Marta) air temperature (T-air) and wind speed (W-speed), from January 13-20, 2018. Measurement conditions as in Figure 6. 
y mayor a 36) y temperaturas del agua menores (la mayoría debajo de $30^{\circ} \mathrm{C}$, aún alrededor del mediodía). Las temperaturas del aire fueron generalmente menores que en abril de 2017 (Figura 6), sin calentarse tanto al mediodía en la mayor parte de días. Los vientos alcanzaron mayores velocidades que en los otros intervalos estudiados. En contraste, cada día ocurrió un enfriamiento nocturno significativo en la superficie de la laguna, el cual temprano en la mañana era $3-6{ }^{\circ} \mathrm{C}$ menor en comparación con el mediodía. Sin embargo, hubo episodios puntuales de enfriamiento de $2-3{ }^{\circ} \mathrm{C}$ en superficie durante la tarde (14:30-18:30) casi cada día, no asociados con disminución de la temperatura del aire o con vientos más fuertes, pero coincidentes con la mitad inferior de la marea saliente, lo cual quizás indica la circulación de masas de agua más frías.

Mezcla luego de lluvia. Luego de un episodio de fuertes lluvias y escorrentía el 2 de octubre de 2018 (14:3020:30), se pudo seguir el comportamiento de la salinidad y la temperatura en la vertical por los siguientes tres días (Figura 9). Unas 12 horas después del episodio (3 de octubre, 07:50), la columna de agua estaba claramente estratificada con menores salinidades $(18,2)$ y temperaturas $\left(27,8^{\circ} \mathrm{C}\right)$ en superficie (vs. 31,3 para salinidad y $30,0{ }^{\circ} \mathrm{C}$ para temperatura a $1 \mathrm{~m}$ de profundidad). Unas 5 horas más tarde (13:10), la salinidad y la temperatura superficiales se habían incrementado respectivamente a 24,4 y $31,3{ }^{\circ} \mathrm{C}$. Al día siguiente (4 de octubre, 14:30), los 0,6 m superiores estaban bien mezclados y más salinos (alrededor de 29) y permanecieron así hasta el día siguiente (5 de octubre, 14:30). En suma, unas 42 horas luego de las lluvias, la columna de agua se mezcló por completo, con una salinidad similar a la del mar adyacente (28,3-28,4; la temperatura fue naturalmente más alta en la laguna que en el mar; Figura 9B, 9C). Cálculos de sigma-t para todos los perfiles verticales (Figura 9D) muestra que, mientras la columna estaba estratificada, la densidad era menor en la superficie; por lo tanto, probablemente la mezcla subsiguiente no ocurrió por intercambio vertical termohalino. Aun cuando el enfriamiento nocturno del 3 al 4 de octubre mostró que la capa superficial se puso mucho más fría que las inferiores (Figura 9A), como la salinidad se mantuvo baja, es poco probable que la densidad en la superficie hubiera sido mayor que las de las capas más profundas como para producir mezcla vertical. En cambio, hubo un ciclo mareal completo con un intervalo de $0,35 \mathrm{~m}$ entre las mediciones del 3 y el 4 de octubre (Figura 9A). Sin descartar efectos del viento (no considerados, ya que no hay medidas locales de viento), la mezcla pudo haber sido ayudada por la circulación impulsada por la marea. episodes of $2-3{ }^{\circ} \mathrm{C}$ surface cooling during the afternoon (14:30 to $18: 30$ ) almost every day, not associated with air temperature decreases or faster winds, but coincident with the lower half of the ebbing tide, somehow indicative of circulation of cooler water masses.

Mixing after rainfall. After a heavy rainfall and runoff episode on October 2, 2018 (14:30 to 20:30), we were able to follow up the behavior of salinity and temperature in the vertical for the next three days (Figure 9). About 12 hours after the episode (October 3, 07:50), the water column was clearly stratified with lower salinities (18.2) and temperatures $\left(27.8^{\circ} \mathrm{C}\right)$ at the surface (vs. 31.3 for salinity and $30.0^{\circ} \mathrm{C}$ for temperature at $1 \mathrm{~m}$ in depth, Figure 9B, 9C). About 5 hours later (13:10) surface salinity and temperature had increased respectively to 24.4 and $31.3{ }^{\circ} \mathrm{C}$. The next day (October 4, 14:30) the upper $0.6 \mathrm{~m}$ were well mixed and more saline (around 29), remaining as such one day later (October 5, 14:30). In sum, about 42 hours after the rainfall the water column was mixed thoroughly with a salinity similar to that of the adjacent sea (28.3-28.4; temperature was naturally warmer in the lagoon than in the sea, Figure 9B, 9C). Sigma-t calculations for all vertical profiles (Figure 9D) show that while the column was stratified, density was lower at the surface, and therefore mixing probably did not occur through vertical thermohaline exchange. Even though the overnight cooling from October 3 to 4 showed the surface layer to become much colder than deeper layers (Figure 9A), as salinity remained low, it is unlikely that the density of the surface would have been greater than that of deeper layers, to elicit vertical mixing. Instead, a full tidal cycle with a range of $35 \mathrm{~cm}$ occurred between measurements on October 3 and 4 (Figure 9A); not discarding wind effects (not considered as there are no local wind measurements), mixing could have been aided by tide-driven circulation.

\section{Light extinction}

La Escollera lagoon waters are usually greenish, with varied transparency. Only after heavy runoff, when sediments from the surrounding hills washed in, did waters temporarily became brown and murky. The following results on extinction coefficients are only for greenish waters, because the days in which light loggers were clean for valid measurements never coincided with brown murky water. There was not a clear pattern of light extinction either with the seasons or with the sea level (data not shown). Extinction coefficients varied between $0.020 \mathrm{~cm}^{-1}$ and $0.065 \mathrm{~cm}^{-1}$, that is, approximately $2 \%$ to 


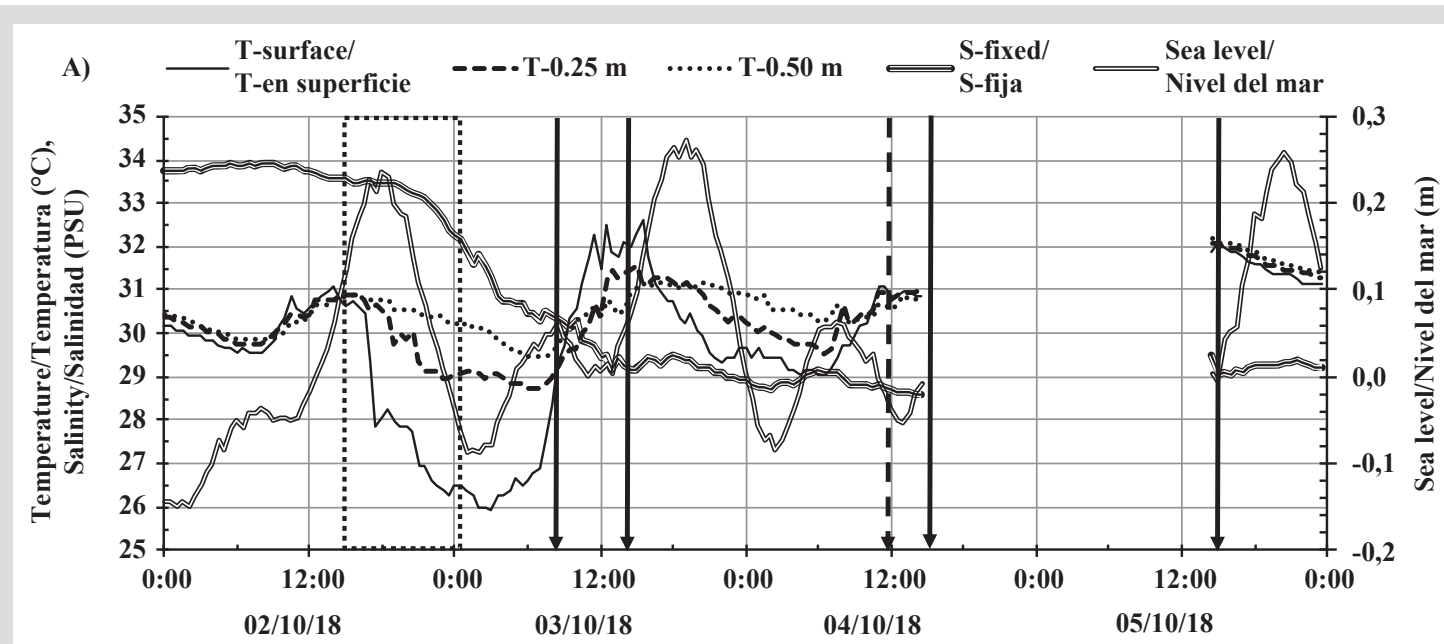

B)

Salinity/Salinidad (PSU)

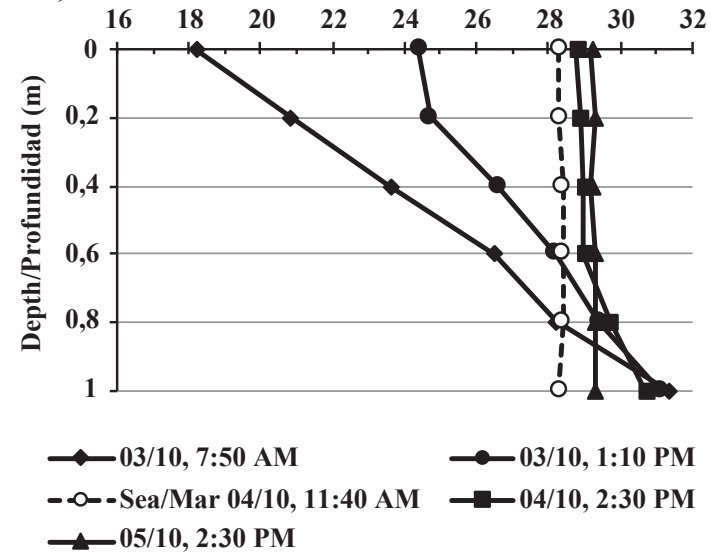

C) Temperature/Temperatura $\left({ }^{\circ} \mathrm{C}\right)$
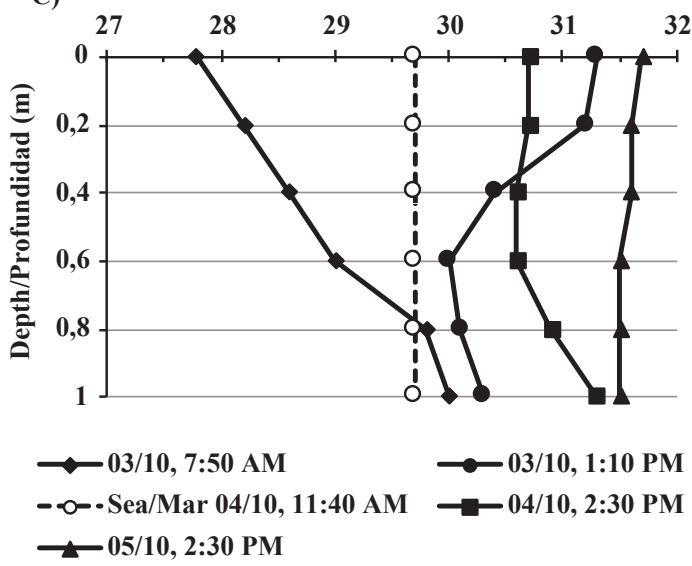

D)

Density/Densidad (sigma-t)

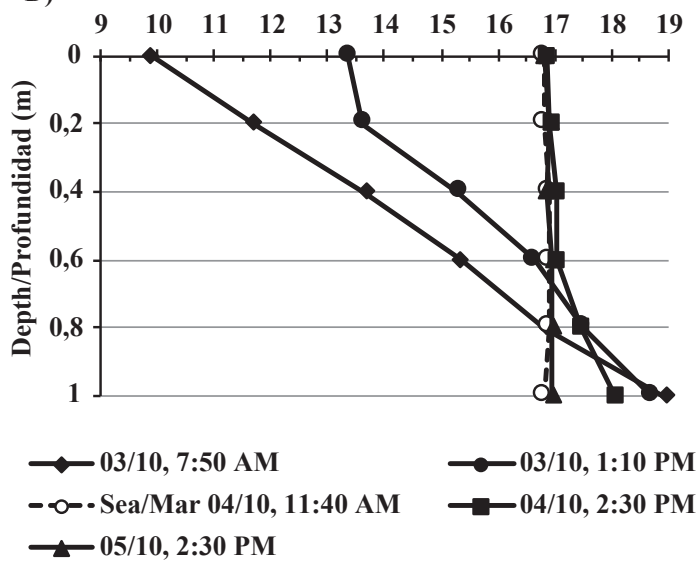

Figura 9. A) Variación de salinidad (S-fija), temperatura (T-en superficie, $0,25 \mathrm{~m}$ y $0,5 \mathrm{~m}$ de profundidad) y nivel del mar (2-5 de octubre de 2018). Condiciones de medición como en la Figura 6 (exceptuando el intervalo en blanco, cuando los registradores se recuperaron para limpieza hasta el otro día). Un episodio de fuertes lluvias, que ocurrió el 2 de octubre desde las 14:30 hasta las 20:30, se marca con un rectángulo de borde discontinuo. Las flechas marcan los momentos de mediciones verticales, que fueron llevadas a cabo con un sensor de mano cada $0,2 \mathrm{~m}$ en el primer metro de la columna de agua. La flecha discontinua marca las medidas hechas en el mar adyacente. Estos perfiles verticales se representan en B) y C). D) Valores de densidad (como sigma-t), calculados de B) y C).
Figure 9. A) Variation of La Escollera lagoon sea-water salinity (S-fixed), temperature (T-at the surface, $0.25 \mathrm{~m}$ and $0.5 \mathrm{~m}$ in depth) and sea level (October 2 to 5, 2018). Measurement conditions as in Figure 6 (excepting the blank interval, when loggers were retrieved overnight for cleaning). A heavy rainfall episode, which occurred on October 2 from 14:30 to 20:30, is marked by the dashed rectangle. Arrows mark moments of point vertical measurements every $0.2 \mathrm{~m}$ for the first $1 \mathrm{~m}$ of the water column, carried out with a handheld sensor; dashed arrow is for a measurement done at the adjacent sea. These vertical profiles are represented in B) and C). D) Density values (as sigma-t) calculated from B) and C). 


\section{Extinción de la luz}

Las aguas de la laguna La Escollera usualmente son verdosas, con variada transparencia. Las aguas se volvieron marrones y turbias solo luego de una fuerte escorrentía, cuando se lavaron sedimentos de las colinas adyacentes. Los siguientes resultados sobre los coeficientes de extinción aplican solo para aguas verdosas porque los días en que los registradores de luz estuvieron limpios para producir datos válidos nunca coincidieron con aguas marrones turbias. No se encontró un esquema claro de extinción de la luz ni con las épocas ni con el nivel del mar (datos no mostrados). Los coeficientes de extinción variaron entre $0,020 \mathrm{~cm}^{-1} \mathrm{y}$ $0,065 \mathrm{~cm}^{-1}$; esto significa que aproximadamente de $2 \%$ a $6,5 \%$ de la intensidad de luz se perdió por cada $1 \mathrm{~cm}$ de profundidad, en comparación con el cm anterior (Tabla 2, Figura 10). En consecuencia, entre $85 \%$ y $100 \%$ de la luz se

Tabla 2. Profundidad en la que la intensidad de luz corresponde a $1 \%$ de la luz incidente en superficie en la laguna La Escollera. Lo anterior fue calculado a partir de la ecuación de extinción de la luz de Beer-Lambert usando el coeficiente de extinción $(k)$ mínimo, promedio y máximo y las intensidades de luz incidente en superficie alrededor del mediodía. Datos de 73 días seleccionados en los que los registradores estuvieron limpios (entre marzo 2017-marzo 2018).
$6.5 \%$ of the light intensity was lost every $1 \mathrm{~cm}$ in depth from the value of the previous $\mathrm{cm}$ (Table 2, Figure 10). Thus, about $85 \%$ to $100 \%$ of the light was lost within the first meter of water. From calculations for the minimum, mean and maximum extinction coefficients and incident light intensities, surface intensities around noon decreased to $1 \%$ at 0.26 to $3.70 \mathrm{~m}$ in depth (mean $1.16 \mathrm{~m}$ ).

\section{DISCUSSION}

After more than 30 years of construction, the condition of La Escollera lagoon ecosystem with its welldeveloped fringe mangrove, is apparently good and healthy. Its trophic status, its main primary producers and drivers, and whether the system is providing the expected nursery and productivity services (e.g., Knoppers, 1994; Duarte

Table 2. Depth at which the light intensity is $1 \%$ of the surface incident light in La Escollera lagoon, calculated from the Beer-Lambert light extinction equation using the minimum, mean and maximum extinction coefficients $(k)$ and incident surface light intensities around noon. Data from 73 days in which the loggers were clean (from March 2017 to March 2018).

\begin{tabular}{|l|c|c|c|}
\hline \multirow{2}{*}{$\boldsymbol{k}\left(\mathrm{cm}^{-1}\right)$} & \multicolumn{3}{|c|}{ Profundidad de la intensidad de luz a 1 \% $(\mathbf{m}) /$ Depth at $\mathbf{1} \%$ light intensity $(\mathbf{m})$} \\
\cline { 2 - 4 } & Mínimo/Minimum & Promedio/Mean & Máximo/Maximum \\
\hline Mínimo/Minimum (0.020) & 0.81 & 2.26 & 3.70 \\
Promedio/Mean (0.040) & 0.42 & 1.16 & 1.91 \\
Máximo/Maximum (0.065) & 0.26 & 0.71 & 1.17 \\
\hline
\end{tabular}

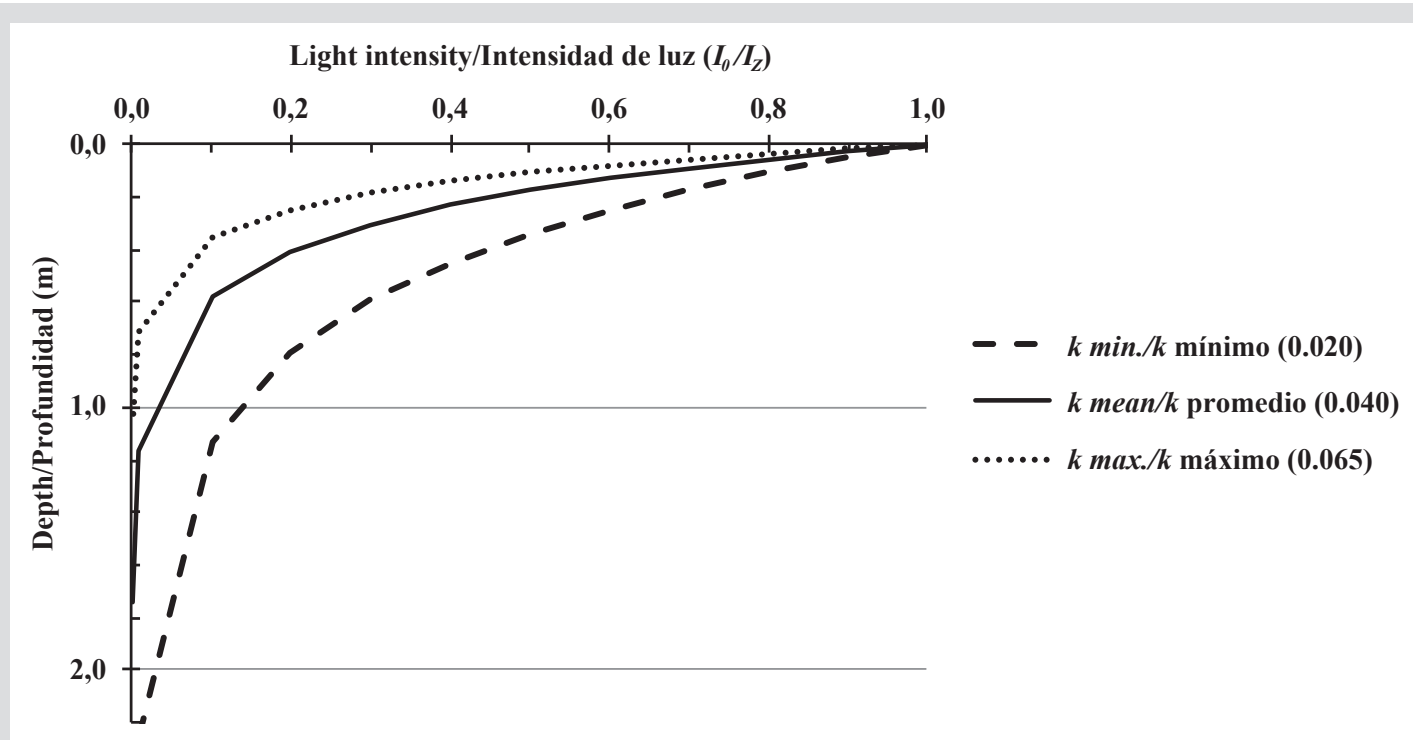

Figura 10. Extinción de la luz en la columna de agua $\left(I_{Z}\right.$ como proporción de la intensidad de luz en superficie, $I_{0}$ ) en función de la profundidad para la laguna La Escollera. Datos y cálculos como en la Tabla 2 (unidades de $k$ son $\left.\mathrm{cm}^{-1}\right)$.
Figure 10. Light extinction in the water column $\left(I_{Z}\right.$ as a proportion of the surface intensity, $I_{0}$ ) as a function of depth. Data and calculations as in Table 2 (units of $k$ are $\mathrm{cm}^{-1}$ ). 
perdió dentro del primer metro de agua. A partir de cálculos del coeficiente de extinción mínimo, promedio y máximo, en relación con la intensidad de luz incidente, se pudo establecer que las intensidades de luz incidente en superficie al mediodía disminuyeron a $1 \%$ desde $0,26 \mathrm{~m}$ hasta $3,70 \mathrm{~m}$ de profundidad (promedio de 1,16 m) (Figura 10); esto indica que la luz puede alcanzar el fondo de la laguna.

\section{DISCUSIÓN}

Luego de más de 30 años de construcción, la condición del ecosistema de la laguna La Escollera, con su bien desarrollado manglar de borde, es aparentemente buena y saludable. Su estatus trófico, sus principales productores primarios y lo que los impulsa y, asimismo, si el sistema está proveyendo los servicios de guardería y producción esperados (v. g. Knoppers, 1994; Duarte y Cebrián, 1996; Nagelkerken et al., 2008; Cloern et al., 2014) son materia de investigaciones en marcha y lo será de futuras. También falta determinar los posibles impactos de derrames de agua de alcantarilla y de actividades náuticas como descargas de agua de sentina e introducción de especies no nativas ( $v . g$. Foster et al., 2016).

Hasta ahora, durante prácticas de cursos y observaciones de campo, se ha visto una epifauna sésil diversa pero temporalmente variable en el sustrato duro disponible (raíces adventicias de mangle, pilotes, paredes de cemento, lados inferiores de placas experimentales de colonización), en especial filtradores, que en ocasiones son afectados por episodios de fuerte escorrentía y sedimentación. Mediciones esporádicas han mostrado valores relativamente bajos de $\mathrm{pH}$ y de oxígeno y valores altos de nutrientes inorgánicos (ver Zea et al., 2017).

La carencia de descarga fluvial constante hace de la laguna La Escollera un estuario negativo, que tiende a ser eurihalino (30-40) y a veces polihalino (18-30) (Vázquez-Botello et al., 2009) y que se ve influenciado principalmente por escorrentía de la cuenca local durante 1luvias. En La Escollera, el esquema estacional de salinidad es similar o mayor (>35, con un máximo de 38,9) al del mar adyacente en la época seca, debido a la evaporación local, e intermitentemente más bajo $(<30$, con un mínimo de 15,1$)$ por dilución en la época de lluvia. Lo anterior lo hace similar al esquema estacional de las lagunas costeras estudiadas que están ubicadas en el Caribe colombiano y que carecen de entradas permanentes de agua dulce. Por ejemplo, Laguna Sur (de la bahía de Chengue), una laguna natural mucho más and Cebrián, 1996; Nagelkerken et al., 2008; Cloern et al., 2014) is a matter of current and future research. Possible impacts from sewage overflow and from boating activities such as wastewater or non-native species introductions (e.g., Foster et al., 2016) also remain to be determined. So far, during course practices and field observations we have seen diverse but temporarily variable sessile epifauna on the available cryptic hard substratum (mangrove stilt roots, pilings, cement walls, undersides of experimental fouling panels), especially filter feeders, often strongly affected by episodes of heavy runoff and sedimentation. Occasional measurements have shown relatively low $\mathrm{pH}$ and oxygen levels, and high inorganic nutrient levels (see Zea et al., 2017).

The lack of a constant riverine runoff makes La Escollera lagoon a negative estuary, which tends to be euryhaline (30-40), sometimes polyhaline (18-30) (Vázquez-Botello et al., 2009), influenced mainly by rain runoff from the local basin. In La Escollera, the seasonal pattern of salinity, similar or higher $(>35$, with a maximum of 38.9) than the adjacent sea during the dry season, owing to local evaporation, and intermittently lower $(<30$, reaching a minimum of 15.1), from dilution during the rainy season, is similar to studied natural coastal lagoons of the Colombian Caribbean that lack a permanent fresh water inputs. For example, Laguna Sur of Chengue Bay, a much wider natural lagoon located in the adjacent NE of Santa Marta, shows salinities from 37 to 42 during the dry season, and 31-35 during the rainy season but dropping to 23-29 after rainfall (Álvarez-León et al., 1995). In Cocoliso, a karstic island lagoon in Isla Grande, Rosario Islands, near Cartagena city, salinity is similar to the sea, perhaps slightly higher (37), but may drop to 29 during rainstorms (Castillo et al., 1992). In Ciénaga de los Vásquez, an ample lagoon with a rather wide opening to the sea, located south of Bahía de Cartagena, salinity is similar to that of the sea (36) during the dry season, lowering (29-34) during the rainy season (Pérez and Victoria, 1977).

Regarding temperature, the shallowness and enclosure of La Escollera are responsible for relatively strong warming from solar radiation, with temperatures as high as $34.7^{\circ} \mathrm{C}$, while coastal waters of Ensenada de Gaira fluctuate around $27-28{ }^{\circ} \mathrm{C}$ (Franco, 2005). The greater warming at the surface in comparison with $0.25 \mathrm{~m}$ and $0.50 \mathrm{~m}$ in depth during the day, often followed by cooling of surface waters at night, behaves as expected in a body of water which warms from the surface down by 
grande localizada en el NE cercano a Santa Marta, muestra salinidades de 37-42 en la época seca y de 31-35 en la época de lluvia, pero baja a 23-29 luego de lluvias (Álvarez-León et al., 1995). Por otra parte, en Ciénaga de los Vásquez, una laguna localizada al sur de la bahía de Cartagena que cuenta con una entrada bastante amplia del mar, la salinidad es similar a la del mar (36) en la época seca y baja (29-34) en la época de lluvia (Pérez y Victoria, 1977).

Con respecto a la temperatura, la poca profundidad y el encerramiento de La Escollera son responsables del calentamiento relativamente fuerte causado por la radiación solar, con temperaturas tan altas como $34,7{ }^{\circ} \mathrm{C}$, mientras que las aguas costeras de la ensenada de Gaira fluctúan alrededor de $27-28{ }^{\circ} \mathrm{C}$ (Franco, 2005). El mayor calentamiento en la superficie en comparación con $0,25 \mathrm{~m}$ y $0,50 \mathrm{~m}$ de profundidad durante el día, frecuentemente seguido de enfriamiento del agua superficial en la noche, se comporta como se espera de un cuerpo de agua que se calienta desde la superficie hacia abajo por radiación incidente en el día y que pierde calor en la noche por convección hacia el aire. Esta laguna se enfría (hasta llegar a $25-26{ }^{\circ} \mathrm{C}$ ) en la época seca. Lo mismo pasa en la cercana Laguna Sur, de la bahía de Chengue, con temperaturas mínimas de $26{ }^{\circ} \mathrm{C}$ en la época seca, atribuidas a la entrada de aguas de afloramiento (Álvarez-León et al., 1995). En contraste, en las lagunas kársticas de Cocoliso y Ciénaga de los Vásquez, cerca de Cartagena, donde no hay afloramiento, las temperaturas son regularmente altas durante todo el año $\left(28-32{ }^{\circ} \mathrm{C}\right)$ y llegan a $26{ }^{\circ} \mathrm{C}$, pero luego de tormentas (Pérez y Victoria, 1977; Castillo et al., 1992).

Este enfriamiento de La Escollera y Laguna Sur probablemente ocurre también por pérdida de calor convectivo y evaporativo, nocturno y por vientos; en la época seca, las temperaturas del aire son ligeramente menores (por el invierno del hemisferio norte) y soplan los fuertes vientos alisios en el área. De hecho, el enfriamiento nocturno de 3-6 ${ }^{\circ} \mathrm{C}$ de la capa superficial de La Escollera es la norma en esta época. Sin embargo, es claro que las aguas frías del afloramiento costero $\left(23-26{ }^{\circ} \mathrm{C}\right.$, cf. Franco, 2005 ) entran en la laguna por la circulación impulsada por la marea. La ocurrencia de picos de enfriamiento superficial de $2-3{ }^{\circ} \mathrm{C}$ durante el día en la época seca en La Escollera, no asociados a bajas temperaturas del aire, podrían ocurrir por hundimiento rápido de aguas superficiales a causa de enfriamiento evaporativo debido al viento (Castillo et al., 1992), pero también por la circulación de las aguas frías del afloramiento costero a través de la laguna. incident radiation during the day, and loses heat at night by convection to the air. This lagoon is cooled (dropping to 25$26^{\circ} \mathrm{C}$ ) during the dry season. The same occurs in the nearby Laguna Sur of Chengue Bay, with minimal temperatures of $26{ }^{\circ} \mathrm{C}$ during the upwelling season (Álvarez-León et al., 1995). In contrast, in the karstic lagoons of Cocoliso and Ciénaga de los Vásquez near Cartagena, where there is no upwelling, temperatures are regularly high throughout the year $\left(28-32{ }^{\circ} \mathrm{C}\right)$, dropping to $26{ }^{\circ} \mathrm{C}$ but after rainstorms (Pérez and Victoria, 1977; Castillo et al., 1992).

This cooling of La Escollera and Laguna Sur probably occurs from nocturnal and wind-driven convective and evaporative heat loss; slightly lower air temperatures (from the northern hemisphere winter) and strong trade winds are present in the area during the dry season. In fact, 3-6 ${ }^{\circ} \mathrm{C}$ nocturnal cooling of the surface layer of $\mathrm{La}$ Escollera are the norm during this time, possible increasing surface water density and thus inducing vertical mixing. However, it is clear that upwelled, cool coastal waters (23-26 ${ }^{\circ} \mathrm{C}$, cf. Franco, 2005) enter the lagoon through tide-driven circulation. The occurrence of spikes of $2-3{ }^{\circ} \mathrm{C}$ of surface cooling during the day in the dry season at $\mathrm{La}$ Escollera, not associated with lower air temperatures, could occur from rapid sinking of surface waters from evaporative cooling by the wind (Castillo et al., 1992) but also from circulation throughout the lagoon of cooler water masses.

The daytime (around noon) vertical profiles (down to $1 \mathrm{~m}$ in depth) of salinity and temperature in La Escollera lagoon show that a well-mixed water column is the norm, excepting after heavy rainfall, when the water column becomes stratified, with surface layers less saline than deeper layers. Vertical profiles also follow the seasonal pattern of cool and salty waters during the dry season, and the warmer and less saline waters during the rainy season. The same seasonal pattern of well-mixed vs. stratified column is seen, but in a larger vertical scale, in the coastal waters of Ensenada de Gaira (Franco, 2005). The occurrence during the dry season of days when the water column was uniformly cool around noon (e.g., $26{ }^{\circ} \mathrm{C}$ ), indicate that upwelled waters are entering the lagoon, rather than being cooled overnight or by wind. In fact, the documented, rather quick mixing (hours to about 2 days) of the stratified water column formed after heavy rainfall, could not be accounted for by vertical exchange from increased density at the surface from overnight cooling, but rather by tide-driven circulation. 
Los perfiles verticales (hasta $1 \mathrm{~m}$ de profundidad) en el día (alrededor del mediodía) de salinidad y temperatura en la laguna La Escollera muestran que la norma es una columna de agua bien mezclada, excepto luego de fuertes lluvias cuando la columna de agua se estratifica, con las capas superficiales menos salinas que las profundas. Los perfiles verticales también siguen el esquema estacional de aguas frías y saladas en la época seca y de más calientes y menos salinas en la época de lluvia. El mismo esquema estacional de columnas bien mezcladas vs. estratificadas ocurre en las aguas costeras de la ensenada de Gaira, pero en una mayor escala vertical (Franco, 2005). La ocurrencia en la época seca de algunos días en que la columna de agua estuvo uniformemente fría al mediodía (v. g. $26{ }^{\circ} \mathrm{C}$ ) indica que las aguas de afloramiento están entrando en la laguna más que estén siendo enfriadas por la noche o el viento. De hecho, la mezcla bastante rápida (de horas hasta cerca de dos días) que fue documentada para la columna estratificada que se formó luego de un fuerte aguacero no puede explicarse por intercambio vertical al aumentar la densidad en superficie por enfriamiento nocturno, pero sí por circulación debida a la marea.

En lagunas costeras estranguladas como $\mathrm{La}$ Escollera, con una sola entrada larga y angosta, se asume que la circulación es impulsada más por vientos y escorrentía que por oscilaciones de la marea porque el canal amortigua las fluctuaciones del nivel del mar (Kjferve y Maguill, 1989; Kjferve, 1994). Sin embargo, la oscilación del nivel del mar dentro de La Escollera sigue la marea astronómica regular mixta del área, siendo de la misma magnitud que la de la costa (datos inéditos). Esto muestra que, de alguna manera, la morfología del canal permite que la marea entre y salga sin que haya, en apariencia, mucha disipación, y esto fuerza la circulación. Quizás porque la laguna está rodeada de manglares altos y no tiene quebradas que desembocan en ella, los vientos y la escorrentía tienen influencia mínima o esporádica en la circulación. Considerando una laguna de 1,5 $\mathrm{m}$ de profundidad y la diferencia mínima $(0,04 \mathrm{~m})$, máxima $(0,44 \mathrm{~m})$ y promedio $(0,19 \mathrm{~m})$ entre marea alta y baja en el mes lunar presentado en la Figura 5, el volumen que entra o sale de la laguna variaría de $0,04 \%$ a 29,3\% (promedio 12,7\%) durante cada intercambio mareal. Con dos entrantes y dos salientes por día, en promedio, un equivalente de alrededor de $51 \%$ del volumen de la laguna sería intercambiado cada día con el mar y alcanzaría $80 \%$ durante las mareas vivas. Para confirmar lo anterior, se requiere un análisis más detallado del papel de la marea en la circulación, el cual se encuentra en desarrollo.
In chocked coastal lagoons like La Escollera, with a single long narrow entrance channel, circulation is assumedly driven more by winds and runoff than by tidal oscillations, because the channel dampens water level fluctuations, significantly reducing tidal oscillation (Kjferve and Maguill, 1989; Kjferve, 1994). However, sea level oscillation inside La Escollera follows the regular astronomical mixed tide for the area, being of about the same magnitude to that at the coast (unpublished work). This shows that somehow the morphology of the channel allows for the tide to ebb and flood apparently without much dissipation, thus forcing circulation. Perhaps by being surrounded by tall mangroves, and not having any streams that open in the lagoon, winds and runoff have a minimal or sporadic influence on circulation, allowing tides to dominate. Considering a lagoon depth of $1.5 \mathrm{~m}$, and the minimal $(0.04 \mathrm{~m})$, maximal $(0.44 \mathrm{~m})$ and mean $(0.19 \mathrm{~m})$ difference between high and low tide during the lunar month depicted in Figure 5, the volume of water entering or leaving the lagoon would vary from $0.04 \%$ to $29.3 \%$ (mean $12.7 \%$ ) during each ebbing or flooding. With two ebbs and two floods per day, on average an equivalent of about $51 \%$ of lagoon volume would be exchanged with the sea each day, reaching $80 \%$ during spring tides. A more detailed analysis of the role of tides in circulation, in progress, would be needed to confirm these assertions.

The light regime of La Escollera lagoon waters is such that primary production in most of the water column is possible. Its greenish waters are indicative of relatively high phytoplankton density and thus of photosynthesis. Measured (morning to noon) oxygen levels are low (ca. $\left.1.7-2.83 \mathrm{mgL}^{-1}\right)$, in comparison to those of the outer canal and the sea (>5 mgL $\mathrm{mL}^{-1}$, cf. Zea et al., 2017), and show that processes that lead to its consumption are significant. Oxygen, primary production and respiration measurements are being undertaken and the results will be published elsewhere. Our water transparency measurements neither showed a seasonal trend, nor were they related to the tide, indicating a complex scenario for the control of phytoplankton biomass. The light extinction coefficients show that light is regularly reaching the bottom, as $1 \%$ of incident light intensity around noon could reach more than $1 \mathrm{~m}$ in depth, and even almost $2 \mathrm{~m}$ in average transparency conditions. Indeed, part of the lagoon bottom supports, apparently seasonally, thick carpets of the green algae Caulerpa sertularioides. 
El régimen lumínico en las aguas de la laguna La Escollera es tal que la producción primaria en la mayor parte de la columna de agua es posible. Sus aguas verdosas son indicativas de una relativamente alta densidad fitoplanctónica y, por lo tanto, de fotosíntesis. Los niveles de oxígeno medidos (de la mañana al mediodía) son bajos (ca. 1,7-2,83 $\mathrm{mgL}^{-1}$ ) en comparación con los del canal exterior y el mar (> $5 \mathrm{mgL}^{-1}$, cf. Zea et al., 2017) y, además, muestran que los procesos que llevan a su consumo son significativos. Se están llevando a cabo mediciones de oxígeno, producción primaria y respiración; los resultados se publicarán por separado. Las medidas de transparencia del agua no mostraron un esquema de variación estacional ni estuvieron relacionadas con la marea, lo que presenta un escenario complejo del control de la biomasa fitoplanctónica. Los coeficientes de extinción de la luz muestran que esta regularmente alcanza el fondo, puesto que $1 \%$ de la luz incidente al mediodía puede alcanzar más de $1 \mathrm{~m}$ de profundidad y hasta casi $2 \mathrm{~m}$ en condiciones promedio de transparencia. En efecto, en parte del fondo de la laguna existen gruesos tapetes del alga verde Caulerpa sertularioides, que parecen ser estacionales.

Las observaciones y datos presentados proveen la base para desarrollar preguntas de investigación sobre el papel de (1) las variables físicas en la circulación y descarga de agua y en el transporte de sedimento (y en mantener el canal abierto); (2) la circulación y su variabilidad en la producción primaria y la respiración, tanto pelágica como bentónica, y (3) eventos extremos de alta escorrentía y sedimentación y de agotamiento de oxígeno en la sucesión de la comunidad epifaunal.

\section{AGRADECIMIENTOS}

Roberto Lemaitre, dueño de la discoteca La Escollera, generosamente permitió la entrada al área para estos estudios. Los celadores, Martín y Ramón, fueron siempre muy amables y serviciales. La sede Caribe de la Universidad Nacional de Colombia financió los costos de los equipos y el programa de Posgrado en CienciasBiología, línea Biología Marina financió los costos del laboratorio y de los cursos. La Universidad Autónoma de Madrid dio respaldo institucional a la estancia académica de NEG-L en el Instituto de Estudios en Ciencias del Mar (Cecimar), Santa Marta. Néstor Campos (sede Caribe) y Pedro Ricardo Dueñas (Universidad de Bogotá Jorge Tadeo Lozano) sirvieron de enlace y dieron soporte conceptual. Ernesto Mancera (sede Bogotá) y Jairo Medina (sede
The above observations and data provide the basis for developing research questions regarding the role of 1) physical variables in circulation, flushing and sediment transport (and in maintaining the channel open); 2 ) circulation and its variability in primary production and respiration, both pelagic and benthic, and 3) of extreme events of high runoff and sedimentation and oxygen depletion in epifaunal community succession.

\section{ACKNOWLEDGEMENTS}

Roberto Lemaitre, owner of La Escollera discotheque, kindly allowed entrance to the area for these studies. The guardsmen, Martín and Ramón, were always very kind and helpful. The Caribbean campus of Universidad Nacional de Colombia funded the costs of equipment, and the Graduate Program in Marine Biology funded lab and course expenses. Universidad Autónoma de Madrid gave institutional support for the academic stay of NEG-L at the Instituto de Estudios en Ciencias del Mar - Cecimar, Santa Marta. Néstor Campos (Caribbean Campus) and Pedro Ricardo Dueñas (Universidad Jorge Tadeo Lozano) served as liaison and gave conceptual support. Ernesto Mancera (Bogotá Campus) and Jairo Medina (Caribbean Campus) carried out graduate course practices in La Escollera and provided insights and data gathered by students. Andrés Osorio (Medellín Campus) advised on physical oceanography. Brigitte Gavio (Bogotá Campus) identified the green alga. Undergraduate students Jessica Reyes (Palmira), Ballantyne Puin (Medellín) and Juan Manuel López (Bogotá) greatly helped during field work. Contribution 497 of Cecimar and of the Graduate Program in Marine Biology, Universidad Nacional de Colombia, sede Caribe. 
Caribe) llevaron a cabo cursos y prácticas de posgrado en La Escollera y proveyeron ideas y datos obtenidos por los estudiantes. Andrés Osorio (sede Medellín) asesoró en oceanografía física. Brigitte Gavio (sede Bogotá) identificó el alga verde. Los estudiantes de pregrado Jessica Reyes (sede Palmira), Ballantyne Puin (sede Medellín) y Juan Manuel López (sede Bogotá) ayudaron significativamente durante el trabajo de campo. Contribución 497 de Cecimar y del programa de Posgrado en Ciencias-Biología, línea Biología Marina, de la Universidad Nacional de Colombia, sede Caribe.

\section{BIBLIOGRAFÍA/LITERATURE CITED}

Álvarez-León, R., G. Ramírez-Triana y E. Wedler. 1995. Registro de las condiciones ambientales de la Laguna Sur (bahía de Chengue, Caribe colombiano) entre 1981-1984. Rev. Acad. Colomb. Cienc., 19(74): 509-525.

Barnes, R.S.K. 1980. Coastal lagoons - The natural history of a neglected habitat. Cambridge University Press, Cambridge. 105 p.

Blanco, J. 1988. Las variaciones ambientales estacionales en las aguas costeras y su importancia para la pesca en la región de Santa Marta, Caribe colombiano. Tesis M. Sc., Biol. Mar., Universidad Nacional de Colombia, Bogotá. 59 p.

Castillo, A., C. Hernández, A. Fresneda, W. Gualteros y L.S. Barbosa. 1992. Caracterización física de la laguna costera de Cocoliso, Isla Grande, Parque Nacional Corales del Rosario, Colombia: 501-511. Mem. VIII Sem. Nal. Cienc. Tecn. Mar, Cong. Centroam. Car. Cienc. Mar, Santa Marta.

Cloern, J.E., S.Q. Foster, and A.E. Kleckner. 2014. Phytoplankton primary production in the world's estuarine-coastal ecosystems. Biogeosciences, 11: 2477-2501.

De Jonge, V.N., M. Elliot, and E. Orive. 2002. Causes, historical development, effects and future challenges of a common environmental problem: eutrophication. Hydrobiologia, 475/476: 1-19.

Duarte, C.M. and J. Cebrián. 1996. The fate of marine autotrophic production. Limnol. Oceanogr., 41(8): 1758-1766.

Elliott, J.A., A.E. Irish, and C.S. Reynolds. 2001. The effects of vertical mixing on a phytoplankton community: a modelling approach to the intermediate disturbance hypothesis. Freshw. Biol., 46: 1291-1297.

Fofonoff, P. and R.C. Millard Jr. 1983. Algorithms for computation of fundamental properties of seawater. Unesco Techn. Pap. Mar. Sci., 44. 53 p.

Foster, V., R.J. Giesler, A. Meriwether, W. Wilson, C.R. Nall, and E.J. Cook. 2016. Identifying the physical features of marina infrastructure associated with the presence of non-native species in the UK. Mar. Biol., 163,173: 1-14. https://doi.org/10.1007/s00227-016-2941-8

Franco, A. 2005. Oceanografía de la ensenada de Gaira: El Rodadero, más que un centro turístico en el Caribe colombiano. Universidad Jorge Tadeo Lozano, Santa Marta. $58 \mathrm{p}$

Gocke, K., E. Mancera, A. Vidal, and D. Fonseca. 2003. Planktonic primary production and community respiration in several coastal lagoons of the outer delta of the Río Magdalena, Colombia. Bol. Investig. Mar. Costeras, 32: 125-144.

Gopal, B., W.J. Junk, and J.A. Davis. (Eds.). 2000. Biodiversity in wetlands: assessment, function and conservation. Vol. 1. Backhuys Publishers, Leiden, $353 \mathrm{p}$.

Hernández, C.A. y K. Gocke. 1990. Productividad primaria en la Ciénaga Grande de Santa Marta, Colombia. An. Inst. Invest. Mar. Punta Betín, 19-20: 101-119.

Kjerfve, B. 1994. Coastal lagoons. 1-8. In: Kjerfve, B. (Ed.). Coastal lagoon processes. Elsevier, Amsterdam. 576 p.

Kjerfve, B. and K.E. Magill. 1989. Geographic and hydrodynamic characteristics of shallow coastal lagoons. Mar. Geol., 88: 187-199.

Knoppers, B. 1994. Aquatic primary production in coastal lagoons. 243-286. In: Kjerfve, B. (Ed.). Coastal lagoon processes. Elsevier, Amsterdam. 577 p.

Lončar, G., I. Bartolić, and D. Bujak. 2018. Contribution of wind and waves in exchange of seawater through flushing culverts in marinas. Tehnički vjesnik, 25(6): 1587-1594.

Lonin, S.A. y L.A. Mendoza. 1997. Evaluación hidrodinámica de las bahías Hooker e Icacos. Bol. Cient. CIOH, 18: 51-64. 
Márquez, G. 1982. Los sistemas ecológicos marinos del sector adyacente a Santa Marta. Caribe colombiano. I. Generalidades. Ecol. Trop., 2(1): 5-19.

Martínez-Clavijo, S. 2013. Diagnóstico actualizado y propuestas de manejo integrado para el balneario El Rodadero, Santa Marta, Caribe colombiano. Trabajo de grado Biol. Mar., Universidad Jorge Tadeo Lozano, Santa Marta. 211 p.

Mitsch, J.W. and J.G. Gosselink. 1993. Wetlands. 2nd ed. Van Nostrand Reinhold, New York. 722 p.

Montaño-Ley, Y., R. Peraza-Vizcarra, and F. Páez-Osuna. 2008. Tidal hydrodynamics and their implications for the dispersion of effluents in Mazatlán Harbor: an urbanized shallow coastal lagoon. Water Air Soil Pollut., 194: 343-357.

Nagelkerken, I., S.J.M. Blaber, S. Bouillon, P. Green, M. Haywood, L.G. Kirton, J.O. Meynecke, J.R. Pawlik, H.M. Penrose, A. Sasekumar, and P.J. Somerfield. 2008. The habitat function of mangroves for terrestrial and marine fauna: A review. Aquat. Bot., 89: 155-185.

Nece, R.E. and R.A. Falconer. 1989. Hydraulic modelling of tidal circulation and flushing in coastal basins. Proc. Instn. Cio. Engrs, Part 1, 86: $913-935$.

Niedda, M. and M. Greppi. 2007. Tidal, seiche and wind dynamics in a small lagoon in the Mediterranean Sea. Estuar. Coast. Shelf. Sci., 74: 21-30.

Parsons, T.R., M, Takahashy, and B. Hargrave. 1984. Biological oceanographic processes (3rd ed.). Pergamon Press, U.K. 330 p.

Pérez, M.E. y C.H. Victoria. 1977. Diversidad y macrofauna de la comunidad de las raíces sumergidas de mangle rojo en la bahía de Cartagena y la ciénaga de los Vásquez. Tesis Biol. Mar., Universidad Jorge Tadeo Lozano, Cartagena. 93 p.

Polanía, J., A. Santos-Martínez, J.E. Mancera-Pineda, and L. Botero Arboleda. 2001. The coastal lagoon Ciénaga Grande de Santa Marta, Colombia. $33-45$. In: Seelinger, U. and B. Kjervfre (Eds.). Coastal marine ecosystems of Latin America. Springer Verlag, Berlin and Heidelberg. 366 p.

Ramírez, G. 1983. Características físico-químicas de la bahía de Santa Marta (agosto 1980-julio 1981). An. Inst. Inv. Mar. Punta de Betín, 13: 111-121.

Ramírez, G. 1990. Distribución de los nutrientes inorgánicos en las aguas costeras de la región de Santa Marta, Caribe colombiano: 244-254. Mem. VII Sem. Nal. Cienc. Tecnol. Mar, Cali.

Rodríguez-Chila, J.D., J.E. Mancera-Pineda y H.J. López-Salgado. 2009. Efectos de la recomunicación del río Magdalena con su antiguo delta: cambios en la producción primaria fitoplanctónica y respiración en el complejo Pajarales, 1989 a 2005. Bol. Investig. Mar. Costeras, 38(2): 119-144.

Salzwedel, H. and K. Müller. 1983. A summary of meteorological and hydrological data from the Bay of Santa Marta, Colombian Caribbean. An. Inst. Invest. Mar. Punta de Betín, 13: 67-83.

Sánchez, R. y S. Zea, 2000. Metabolismo de nitrógeno y fósforo inorgánicos disueltos en la columna de agua en una laguna costera tropical (Caribe colombiano). Carib. J. Sci., 36(1-2): 127-140.

Vázquez-Botello, A., F. Contreras-Espinosa, G. De La Lanza-Espino, and S. Villanueva F. 2009. Primary production in coastal lagoons. $339-361$ In: Isla, F.I. and O. Iribarne (Eds.). Coastal zones and estuaries. Encyclopedia of Life Support Systems (EOLSS), 1. Unesco, Paris. 540 p.

Velásquez-Montoya, L. and M.F. Overton. 2017. Impacts of seasonal forcings on the hydrodynamics of Oregon Inlet, NC. Coast. Dynam., 55: 1240-1250.

Zea, S., N.H. Campos y J.E. Mancera-Pineda (Eds.). 2017. Procesos ecológicos y oceanográficos en lagunas costeras: el caso de La Escollera en Santa Marta. Reconocimiento general y avances 2014-17. Informe inédito, Universidad Nacional de Colombia, sede Caribe, Santa Marta. 62 p. http://bdigital.unal. edu.co/71339/ 